\title{
POLÍTICA EM TEMPOS DE REVOLUÇÃO DO PORTO: CONSTITUCIONALISMO E DISSENSO NO MARANHÃO ${ }^{1}$
}

\section{POLÍTICA EN TIEMPOS DE REVOLUCIÓN DEL PUERTO: CONSTITUCIONALISMO Y DISENSIÓN EN MARANHÃO}

\section{POLITICS AT THE TIME OF THE OPORTO REVOLUTION: CONSTITUTIONALISM AND DISSENT IN MARANHÃO \\ POLITIQUE AU TEMPS DE LA RÉVOLUTION DE PORTO : CONSTITUTIONNALISME DISSENSIONS AU MARANHÃO}

DOI: $10.5533 / 1984-2503-20124101$

\section{Marcelo Cheche Galves ${ }^{2}$}

\section{RESUMO}

O artigo analisa a movimentação política na capitania do Maranhão - província a partir de outubro de 1821, tomando como base as expectativas geradas pela Revolução do Porto, vitoriosa em agosto de 1820. O Maranhão adere à Revolução em abril de 1821, em um movimento capitaneado pelo próprio governador, Bernardo da Silveira Pinto da Fonseca, figura vinculada ao "tempos do Absolutismo". Desde então, disputas políticas são potencializadas pelos novos ares constitucionais, respirados nas praças e materializados nos prelos. Demandas distintas revestem-se de um constitucionalismo polissêmico, heterogêneo em suas motivações e práticas. Tais motivações serão exploradas com ênfase nas razões para o dissenso, expresso por intermédio das urnas, abaixo-assinados, folhetos e jornais.

Palavras-chave: política; imprensa; Maranhão; Revolução do Porto.

\section{RESUMEN}

\footnotetext{
${ }^{1}$ Esse texto recupera e reelabora fragmentos de minha tese de doutorado. Galves, Marcelo Cheche (2010). "Ao público sincero e imparcial": Imprensa e Independência do Maranhão (1821-1826).Tese (Doutorado em História) - Programa de Pós-Graduação em História Social, Universidade Federal Fluminense, Niterói. Essa pesquisa integra o projeto O Maranhão nas Cortes constitucionais portuguesas (1821-1822) e conta com o financiamento da Fundação de Amparo à Pesquisa e ao Desenvolvimento Científico e Tecnológico do Maranhão (FAPEMA).

2 Professor do Departamento de História e Geografia da Universidade Estadual do Maranhão, e professor vinculado ao Programa de Pós-Graduação e Desenvolvimento Socioespecial e Regional da mesma Universidade. E-mail: marcelocheche@ig.com.br
} 
El artículo analiza el movimiento político en la capitanía de Maranhão - provincia a partir de octubre de 1821, tomando como base las expectativas generadas por la Revolución del Puerto, victoriosa en agosto de 1820. Maranhão adhiere a la Revolución en abril de 1821, en un movimiento capitaneado por el propio gobernador, Bernardo da Silveira Pinto da Fonseca, figura vinculada a los "tiempos del Absolutismo". Desde entonces, disputas políticas son potencializadas por los nuevos aires constitucionales, respirados en las plazas y materializados en imprentas. Demandas distintas se revisten de un constitucionalismo polisémico, heterogéneo en sus motivaciones y experiencias. Tales motivaciones serán exploradas con énfasis en las razones para la disensión, expresada por intermedio de las urnas, peticiones, folletos y periódicos.

Palabras-clave: política, prensa, Maranhão, Revolución del Puerto.

\section{ABSTRACT}

The article analyses political movements in the Maranhão captaincy - which became a province in October 1821 based on the expectations generated by the Oporto Revolution, victorious in August 1820. The Maranhão aligned itself to the revolution in April 1821 in a movement captained by the governor himself, Bernardo da Silveira Pinto da Fonseca, who was linked to the "ages of Absolutism". Political disputes were henceforth catalysed by the new constitutional stirrings, breathed in the squares and materialized in the press. Distinct demands were dressed up as a polysemic constitutionalism, heterogeneous both in its motives and practices. Such motives are explored with an emphasis on the reasons behind the dissent expressed at the ballot boxes and in petitions, flyers and newspapers. Key words: politics, press, Maranhão, Oporto Revolution.

\section{RÉSUMÉ}

Cet article analyse l'agitation politique de la capitainerie du Maranhão - qui deviendra une province en octobre 1821 sur la base des expectatives créées par la Révolution victorieuse de Porto en août 1820. Le Maranhão a adhéré à la Révolution en avril 1821 par l'entremise d'un mouvement dirigé par le gouverneur lui-même, Bernardo da Silveira Pinto da Fonseca, un personnage pourtant lié aux « temps de l'absolutisme ». À partir de moment-là, les conflits politiques prendront de l'ampleur grâce au nouveau climat constitutionnel que l'on sentait prendre forme sur les places et dans la presse. Différentes revendications se drapèrent d'un constitutionnalisme polysémique et hétérogène dans ses motivations et ses pratiques. De telles motivations seront étudiées en s'attachant tout 
particulièrement aux raisons des dissensions exprimées dans les urnes, les pétitions, les tracts et les journaux.

Mots-clés : politique; presse; Maranhão; Révolution de Porto.

A partir de abril de 1821, um novo ambiente político pôde ser vislumbrado no Maranhão, especialmente na capital São Luís. Do Grão-Pará e Rio Negro e da Bahia, não chegaram apenas notícias da "adesão" ao movimento constitucional do Porto, mas também da derrubada de governos e instalação de juntas escolhidas pelos agora cidadãos, ampliando, sobremaneira, as possibilidades de participação na vida política. Para André Roberto de Arruda $\mathrm{Machado}^{3}$, o vintismo transferiu para a província, nova denominação das capitanias, a esfera decisória sobre qual governo eleger, dando forma à noção de "partidos", que à luz dos ditames constitucionais, passaram a se enfrentar.

Em São Luís, tais mudanças geraram disputas que se consubstanciaram em torno da permanência do governador Bernardo da Silveira Pinto da Fonseca e /ou da eleição de uma Junta de Governo ${ }^{4}$, a ser decidida por eleições, marcadas para 13 de abril de 1821 , sete dias após Pinto da Fonseca ter anunciado a "adesão" do Maranhão à nova ordem política. A primeira "semana constitucional" foi agitada: convocações, abaixo-assinados, prisões, deportações e pasquins afixados em lugares públicos. As tensões entre um espaço público de representação política, em gestação, e os mecanismos de controle e proibição das ideias divergentes, ditaram o ritmo das disputas.

Os "partidos", inicialmente identificados como "pró" e "contra" a permanência de Pinto da Fonseca à frente do governo, manifestavam-se abertamente, em praça pública para onde parte da discussão política havia se transferido. Enquanto buscava legitimar-se internamente, ante as incertezas do tempo, Pinto da Fonseca encaminhou documentos ${ }^{5}$

\footnotetext{
${ }^{3}$ Machado, André Roberto de Arruda (2006). A quebra da mola real das sociedades. A crise política do Antigo Regime Português na província do Grão-Pará (1821-1825). Tese (Doutorado em História) - Programa de Pós-Graduação em História Social, Universidade de São Paulo, São Paulo, p. 93-95.

${ }^{4}$ Havia, ainda, uma proposta intermediária, em que Pinto da Fonseca presidiria a Junta.

${ }^{5}$ Ao ministro Thomaz Antonio de Villanova Portugal, com pedido para que encaminhasse ao rei, enviou os Acontecimentos políticos ocorridos na capital do Maranhão no dia seis de abril (1821). Biblioteca Nacional (BN), Seção de Manuscritos, 5, 4, 15; ao Congresso português, a Exposição do Governador do Maranhão Bernardo da Silveira Pinto ao congresso português sobre o juramento à constituição que houver de fazer o mesmo congresso, e estabelecimento do Governo Provisório (1821). Instituto Histórico e Geográfico Brasileiro (IHGB), lata 58, pasta 35. Posteriormente, escreveu a Singela e verdadeira narração do começo,
} 
ao rei e às Cortes resumindo os últimos acontecimentos e dando ênfase a "aclamação" de seu nome, único capaz de conduzir aquelas mudanças sem derramamento de sangue. Tais registros revelam quão delicada era sua situação. A ascendente carreira militar fora pautada por laços de fidelidade com a família real ${ }^{6}$, que the valeram a nomeação para governador da capitania, em 1819. Agora, as expectativas geradas nas tropas e nos setores ligados ao comércio e a agricultura de que o constitucionalismo seria capaz de, num só golpe, restabelecer a soberania nacional - abalada por anos de presença militar francesa, depois substituída pela subserviência aos ingleses ${ }^{7}$-, e desonerar a economia provincial $^{8}$, combalida pelo aumento da carga tributária provocado pela estada da Corte no Brasil, o pressionavam a uma decisão que poderia lhe causar prejuízos políticos irreversíveis.

Às pressas e como parte desse novo ambiente político, começou a circular, ainda em abril, o Conciliador, primeiro jornal da província ${ }^{9}$. O intervalo de apenas nove dias entre a "adesão" e a primeira edição do jornal evidencia o vínculo entre a nova ordem política e a construção, via imprensa, de uma nova legitimidade. Seus redatores, José Antonio da Cruz Ferreira Tezo (o padre Tezinho) e Antonio Marques Costa Soares eram figuras ligadas a Meirelles e a Pinto da Fonseca. Alvo dos opositores, a casa de Tezinho foi denunciada como local em que nas madrugadas se articulavam "planos de traição e aleivosia, métodos de suborno e elaboração de pasquins" "10; já Costa Soares acumulava

progresso e conclusão da Regeneração Política do Maranhão, no glorioso dia 6 de abril de 1821 (s/d). Seção de Obras Raras, Coleção Benedito Ottoni.

${ }^{6}$ Ele e Rodrigo Pinto Pizarro, seu ajudante de ordens, pertenciam a famílias de militares que lutaram contra os franceses na Península lbérica e, posteriormente, participaram das campanhas no Prata. Ainda em Portugal, Francisco Homem de Magalhães Quevedo Pizarro, tio de Rodrigo, foi nomeado comandante das forças de vanguarda da província de Traz dos Montes, então governada pelo Conde de Amarante, sogro de Fonseca. Já no Brasil, Quevedo Pizarro foi nomeado governador do Maranhão, cargo que não assumiu por motivo de doença, sendo substituído por Fonseca, que nomeou Rodrigo como seu ajudante. De volta a Portugal, em 1822, Fonseca e Pizarro receberam títulos e cargos, após o restabelecimento dos poderes de D. João VI, em 1823. Ver: Vieira da Silva, Luís Antonio (1972) História da independência da província do Maranhão (1822-1828), 2 ed. Rio de Janeiro: Companhia Editora Americana, p. 58-60 (Coleção São Luís, v. 4) e Pizarro, Rodrigo Pinto (1832) e Carta de um português emigrado acerca do ex-imperador do Brasil e do seu chamado manifesto, Lisboa (Paris, 20/2/1832). BN, Seção de Obras Raras.

${ }^{7} \mathrm{O}$ movimento do Porto, em Portugal e no Maranhão, teve uma forte presença militar. Lá como cá, o aumento dos soldos e a reorganização da carreira militar estiveram entre as primeiras medidas para recobrar a tranqüilidade e instaurar a nova ordem política.

${ }^{8}$ À frente do Corpo de Comércio e Agricultura estava o negociante Antonio José Meirelles, figura-chave na composição política que viabilizou o "governo constitucional" de Fonseca: Meirelles foi o responsável pelo recolhimento das 270 assinaturas pró-permanência de Pinto da Fonseca, dando ares de "aclamação" à sua eleição, em 13 de abril.

${ }^{9}$ Inicialmente manuscrito, o jornal passou a ser impresso a partir da edição de no 34 , de 15 de novembro de 1821, momento de instalação da Tipografia Nacional do Maranhão, a primeira da província, sob controle da administração de Pinto da Fonseca.

${ }_{10}$ Mesquita, José de Loureiro (1821). Manifesto de todos os acontecimentos e causa da Revolução da Província do Maranhão concluída em 6 de abril de 1821. Para servir de justificação aquelles que foram 
funções no governo, a direção da Tipografia, além de ser o responsável pelas peças encenadas no Teatro União - chamado de "Nacional" pelo Conciliador.

Nas páginas do Conciliador, certa leitura da nova ordem política foi construída a partir de um "consenso geral" em torno da permanência de Pinto da Fonseca a frente do governo. Porém, o próprio jornal, na medida em que os opositores repercutiram nos prelos de Lisboa e Londres a situação política da província, revelou a fragilidade de tal consenso. Ao refutar as principais acusações, promoveu uma tensa interlocução sobre a dinâmica política provincial. As razões para o dissenso conduzem as páginas que seguem.

Duas propostas distintas pautaram as primeiras discussões sobre a composição do primeiro governo constitucional. "Aclamado", Pinto da Fonseca apresentou-se como a liderança "natural" da nova ordem política. Ante a proposta de criação de uma Junta Governativa, como ocorrera no Grão-Pará e Rio Negro e na Bahia ${ }^{11}$, o Conciliador, já em sua primeira edição, questionava,

(...) qual será mais bem regido nas delicadas circunstâncias em que estão os domínios portugueses? Um país regido por governos compostos de muitos membros, pela maior parte noviços na grande arte de reger o povo, e talvez suspeitosos do mesmo povo, ou governado por um só homem prático nos deveres relativos ao seu cargo, respeitável em virtudes, ativo em providências e, sobretudo, amado dos mesmos povos que tem regido? Pode alguém preferir a incerteza do acaso à realidade da experiência? Basta $^{12}$.

Derrotados, os grupos que associaram a "adesão" ao acesso a cargos públicos e a um possível reordenamento das relações de poder na província deram início às primeiras acusações contra Pinto da Fonseca. Em síntese, atribuíram o fracasso da proposta a

injustamente presos e perseguidos pelo despótico Governador daquela Província Bernardo da Silveira Pinto, Lisboa: Impressão de Alcobia. BN, Seção de Obras Raras, p. 18.

${ }^{11} \mathrm{O}$ reconhecimento, por parte das Cortes, das juntas provinciais, eleitas em substituição ao antigo sistema de capitães-generais, ocorreu nos casos do Grão-Pará e Rio Negro e da Bahia, em janeiro e fevereiro de 1821, respectivamente. No entanto, apenas em outubro de 1821 as Cortes aprovaram um projeto que, entre outras determinações, estabeleceu a obrigatoriedade da eleição de juntas provinciais. Em documento encaminhado ao rei e às Cortes, em dezembro de 1821, 65 cidadãos reclamaram pelo fato de a junta ainda não ter sido instituída no Maranhão, "província em que os ares constitucionais ainda não haviam chegado". Protesto de lealdade e reconhecimento do povo ao Rei (1821). IHGB. Coleção Instituto Histórico, lata 400, pasta 10 , documento 2 .

${ }_{12}$ Conciliador, no $1,15 / 4 / 1821$, p. 4. Na edição número 3, um artigo assinado por Um português considerou as eleições como "mera formalidade em tempos de crise". Conciliador, no 3, 22/4/1821, p. 29. 
algumas manobras tramadas pelo governador, a saber: 1 - O planejamento, juntamente com alguns militares de sua confiança, da "adesão", forma de conter as pressões para que essa se efetivasse e de, ao mesmo tempo, manter-se à frente do governo da província; 2 - O aumento da tabela de soldos, forma de atrair / neutralizar os setores das tropas que imaginaram outro desfecho para o movimento constitucional; 3 - A recusa em aceitar a chefia de uma Junta de Governo e o anúncio de sua despedida da província como partes da estratégia de permanência à frente do governo, sustentada pelo "apelo popular"; 4 - A criação, em 9 de abril, de uma Junta Consultiva de governo ${ }^{13}$, paliativo contra uma efetiva reorganização das relações de poder na província; 5 - O ordenamento da prisão dos principais opositores, sob o argumento de incitação dos escravos, acusação perigosa, corporificada em alguns pasquins espalhados pela cidade, também por ordem de Fonseca; 6 - Além das prisões, a responsabilidade pelo clima de ameaças que marcou as eleições, restritas, por intermédio de convites, quase que exclusivamente aos cidadãos que o apoiavam ${ }^{14} ; 7$ - O recolhimento de assinaturas em seu apoio como forma de transformar as eleições, marcadas para o dia 13 de abril, em "aclamação" de seu nome ${ }^{15}$.

Parte dessa oposição foi expulsa do Maranhão, alguns de seus membros publicizaram tais acusações nos prelos de Lisboa e Londres, além de se dirigirem às recém-constituídas Cortes portuguesas, expressão maior dos novos tempos e, se acreditava, instância capaz de resolver as disputas provinciais em torno da observância do constitucionalismo em vigência.

O major José de Loureiro Mesquita, por exemplo, publicou em Lisboa, para onde fora deportado em 1821, o Manifesto de todos os acontecimentos e causa da Revolução da Província do Maranhão, concluída em 6 de abril de 1821. Em suas palavras, o autor "organizou discussões", "espreitou a opinião pública", "discursou em praça" e "exigiu a eleição de uma junta constitucional". Acusado de insuflar os escravos a se rebelarem, foi preso e deportado no dia 12 de abril. Sua narrativa ocupou-se em reunir provas do caráter anticonstitucional de Fonseca e das manobras que fizera para permanecer no posto, mesmo contrariando setores importantes das tropas, ao qual o autor pertenceria.

\footnotetext{
${ }^{13}$ Presidida pelo bispo Joaquim de Nossa Senhora de Nazaré. Esse mesmo frade foi eleito presidente da Junta Provisória que substituiu Pinto da Fonseca a partir de fevereiro de 1822.

${ }_{14}$ Um resumo do ambiente que teria marcado as eleições pode ser consultado na Folha Medicinal, no 9, 6/5/1822, p. 70-72.

${ }^{15}$ As eleições terminaram com 86 votos a favor de Fonseca, 8 pela criação de uma Junta e 2 contrários à "adesão". A lista com 270 assinaturas, apresentada no momento da eleição, foi posteriormente publicada pelo Conciliador, no 5, 29/4/1821, p.35.
} 
As palavras de Mesquita transparecem as cisões dentro das tropas, tratadas por Fonseca de maneira una nos documentos encaminhados ao rei e as Cortes, e definidas como "fiéis", "ordeiras" e "constitucionais". As tropas teriam elaborado uma petição ${ }^{16}$ em que manifestaram o desejo da "adesão", prontamente atendido por Fonseca. É importante registrar que a petição foi encabeçada por Manoel de Sousa Pinto de Magalhães e Ricardo José Coelho, militares que acompanharam Fonseca por toda a sua administração e, por várias vezes, foram alvos das representações encaminhadas às Cortes. O major Rodrigo Pinto de Pizarro, ajudante de ordens e também figura-chave do aparato militar de Fonseca, não assinou a petição, talvez com o objetivo de caracterizar os anseios das "tropas", a serem acatados pelo "governo", para o qual emprestava os seus serviços ${ }^{17}$.

Para Mesquita, a "adesão" também foi motivada pelas tropas, mas por seus setores "verdadeiramente constitucionais", cujos nomes, posteriormente, compuseram documentos contra a administração de Fonseca. A pressão desse grupo teria motivado Fonseca a arquitetar um plano de "adesão" a partir dos militares de sua confiança, como Pizarro, Magalhães e Coelho ${ }^{18}$, que ainda "clamariam" por sua permanência à frente do governo.

Essas e outras acusações tinham como pressuposto as relações político-familiares de Fonseca, sempre realçadas. Como ponto de partida, Mesquita lembrou o fato de Fonseca ser genro do $1^{\circ}$ Conde de Amarante, Francisco da Silveira Pinto da Fonseca, militar que participou da luta contra os franceses e se opôs à Revolução do Porto ${ }^{19}$. Tais vínculos com o ancien régime contrastariam com a "legitimidade popular" do novo governo, constituído em "praça pública". Ao major Rodrigo Pinto Pizarro, ajudante de ordens de Fonseca, denunciou por tê-lo advertido sobre os riscos que correria votando contra a permanência de Fonseca. Pizarro teria afirmado que: "quatro peças de Artilharia,

\footnotetext{
${ }^{16}$ No mesmo conjunto de anexos aos documentos encaminhados ao rei e às Cortes, estão as atas das Câmaras de 6 e 13 de abril, com 132 e 69 assinaturas, respectivamente. Registre-se que, a primeira ata, mais abrangente, versava sobre a "adesão", já a segunda, sobre a permanência de Pinto da Fonseca à frente do governo. Acontecimentos políticos... Op. cit.

${ }_{17}^{17}$ Nos registros que produziu sobre o momento, Fonseca sustenta a centralidade da atuação de Pizarro na articulação entre a "adesão" das tropas e o seu consentimento. Fonseca (s/d). Op. cit.

${ }^{18}$ Pizarro e Coelho lutaram juntos nas guerras do Prata e, antes, Pizarro e Magalhães estiveram juntos na tomada de Badajoz. Fonseca (s/d). Op. cit., p. 2-4.

${ }_{19}$ Seu filho, o general Manuel da Silveira Pinto da Fonseca, ㄴo Conde de Amarante, participou ativamente do movimento de resistência às Cortes portuguesas, que culminou com a Revolta de Vila Francada, vitoriosa em abril de 1823. Paixão e Dores, frei Manuel Moreira da (1972). Diário da armada da independência, 2 ed. Brasília: MEC / Instituto Nacional do Livro, p. 67, registrou as notícias chegadas de Portugal em 1823, dando conta de "indisposições contra a Constituição", lideradas pelo $2^{\circ}$ Conde de Amarante.
} 
e mais de mil baionetas, com dez cartuchos embalados, apóiam o meu voto,20. Tais palavras seriam uma reação ao discurso feito por Mesquita, momentos antes da "aclamação": "Nunca convirei n'outra forma de governo, e muito menos no governo de um só, porque seria tornar outra vez a tomar nos pulsos os grilhões do Despotismo que o grito geral da nação nos acaba de despedaçar,21.

Contudo, antes dos ecos do degredo circularem impressos pelas ruas de São Luís, as primeiras edições do Conciliador já expressavam, talvez sem desejar, as fissuras da nova ordem política. Sem declinar nomes, o jornal registrou a decepção daqueles que desejavam uma Junta Provisória já em abril de 1821, "meros entusiastas de fórmulas incompatíveis com o caso,22. O "caso" exigia a permanência de Pinto da Fonseca, único homem capaz de garantir a propriedade e evitar os "riscos da anarquia e da discórdia", como declarou a Câmara ${ }^{23}$, após o resultado das eleições de 13 de abril.

A praça, espaço que simbolizava a novidade política, vivia sob constante vigilância. No mesmo 13 de abril, os escravos foram proibidos de transitar pelo Largo do Palácio, medida tomada para evitar "desordens e alaridos" que atrapalhassem os que deviam decidir $^{24}$. Dias depois, Fonseca encaminhou um documento às Cortes enfatizando a importância de se preservar o sossego num país coberto pela escravatura ${ }^{25}$. No Teatro União, em meio às comemorações constitucionais organizadas pelo redator Costa Soares, o jornal observou um murmúrio "quase nulo" e um apoio "quase geral" ao governo ${ }^{26}$.

Aos poucos e a contragosto, o Conciliador viu-se obrigado a tratar mais detidamente dos "tumultos de abril de 1821 "27, tema incômodo para quem até o momento priorizara a tranqüilidade promovida pela permanência de Pinto da Fonseca; também aos poucos, foram apresentados os "amotinadores e seduzidos" que teriam levado Fonseca a tomar medidas duras, ordenando afastamentos, prisões e deportações.

Os primeiros ecos do degredo foram ouvidos entre novembro e dezembro de 1821 , momento que marca o início de uma intensa interlocução atlântica. Em São Luís

\footnotetext{
${ }^{20}$ Mesquita (1821). Op. cit., p. 13.

21 Ibidem, p. 10.

22 Conciliador, no 2, 19/4/1821, p. 12.

${ }^{23}$ Conciliador, nํ 3, 22/4/1821, p. 36.

${ }^{24}$ Conciliador, no 6, 3/5/1821, p. 44-45.

${ }^{25}$ Carta de Bernardo da Silveira às Cortes em 30 de abril de 1821, publicada no Conciliador, no 8, 10/5/1821, p. 58.

${ }^{26}$ Observações feitas, respectivamente, nas edições no 2, 19/4/1821, p. 14, e nำ4, 26/04/1821, p. 32 .

${ }^{27}$ Situação reconhecida na edição nำ40, 28/11/1821, p. 8.
} 
chegaram a edição nำ 157 do Correio Braziliense ${ }^{28}$, folhetos "anti-Fonseca”, e notícias de denúncias contra sua administração, levadas às Cortes ${ }^{29}$ - também nas Cortes, tramitava a devassa instaurada por ordem de Fonseca, em abril de $1821^{30}$. Entre os folhetos, constavam as Violências feitas no Maranhão por B. da S. P. (Bernardo da Silveira Pinto), - Manifesto justificativo de M. P. de C. (Manoel Pereira de Carvalho) e o Almocreve das petas $^{31}$, atribuídos, por Costa Soares, ao comerciante Manoel Pereira de Carvalho e a Pedro Antonio do Nascimento, alcunhado de "Pai Pedro"32. Na mesma época, o major José de Loureiro Mesquita, já apresentado, publicou em Lisboa o Manifesto de todos os acontecimentos... ${ }^{33}$

Nesses registros o foco recaiu sobre o "despotismo" de Fonseca - termo tomado como oposto ao constitucionalismo dos novos tempos, expresso pelas Cortes. Polissêmico, o "despotismo" no Maranhão poderia ser visualizado nas demonstrações de afeto a figuras ligadas ao absolutismo; nas primeiras atitudes de Fonseca contra 0 movimento constitucional; ausência de uma Junta de Governo; rígido controle da tipografia, recém-instalada; uso político do Conciliador; prisões sem formação de culpa; punições por opiniões emitidas; demissão e remoção arbitrária de empregados da administração; ilegalidade nos contratos públicos, enfim, em toda sorte de práticas condenadas por aqueles que, por variados interesses, exigiam Constituição.

Entre as mais freqüentes acusações, estava aquela que punha em xeque os princípios constitucionais de Fonseca, comprometidos pelos já salientados vínculos com o conde de Amarante e seu filho. A pompa das exéquias organizadas na cidade de São Luís ao conde de Amarante, falecido no ano de 1821 , reforçava tais suspeitas ${ }^{34}$. Ao

\footnotetext{
${ }^{28}$ A partir daqui $C B$.

${ }^{29}$ Na sessão das Cortes no 173, de 11 de setembro de 1822, o deputado Muniz Tavares acusou Fonseca de despotismo. No suplemento ao n 49 do Conciliador, 31/12/1821, o major Rodrigo Pinto Pizarro refutou tal acusação.

${ }^{30} \mathrm{Em}$ novembro de 1821, as Cortes remeteram o processo para a "instância devida". A devassa terminou com a absolvição de todos os envolvidos. Autos da devassa a que procedeu o governador do Maranhão por ordem do governador das armas daquela província, contra os perturbadores do sossego público na capital da mesma província, que se opuseram ao sistema constitucional. Ministério dos Negócios eclesiásticos e de justiça, maço 102, no 1 .

${ }^{31}$ Em dezembro de 1821, o jornal anunciou a chegada da galera Jaquiá, "carregada de folhas de papel pardo, apelidadas Violências feitas no Maranhão por B. da S. P.". Conciliador, suplemento ao nº 46, 20/12/1821, p. 2. Tive acesso a fragmentos desses folhetos a partir da Refutação dos escandalosos folhetos denominados 'Violências'... e 'Manifesto justificativo...' publicados como suplemento aos números 56 e 62 do Conciliador e assinados por Costa Soares.

32 "Pai Pedro" era uma alusão ao "Pai Maranhão", forma pejorativa pela qual o jornal se referia a Honório José Teixeira, provável financiador dos folhetos, apresentado adiante.

${ }^{33}$ Mesquita (1821). Op. cit.

${ }^{34}$ No Protesto... (1821). Op. cit., os cidadãos denunciaram o disparate das homenagens ao Conde de Amarante, superior às que a cidade assistiu por ocasião do falecimento da rainha Maria I. O documento
} 
argumento dos "vínculos familiares" de Fonseca, Costa Soares retrucou: "Só nos costumes de bárbaros incultos, de selvagens cruéis é que se encontra a odiosa prática de punir nos descendentes os crimes dos antepassados (...) Deve a glória do General Silveira ser uma vítima de expiação?"35.

Sabidamente, não era uma questão de fardo dos antepassados. As relações familiares e políticas mantidas por Fonseca até então diziam muito sobre as posições que assumira. Quando a Revolução do Porto chegou ao Pará, Fonseca expediu uma Ordem Circular aos comandantes de Distrito alertando para a "insurreição da província do Pará", precavendo-os sobre a introdução de emissários e de papéis incendiários e pedindo a "correção" dos que espalhassem ideias perigosas pelo Maranhão. O raciocínio era pragmático: como alguém que tomou providências contra o movimento constitucional no Pará - chamado de insurreição -, três meses antes, tornara-se agora o paladino do constitucionalismo no Maranhão? Costa Soares refutou esse argumento com digressões sobre os possíveis sentidos de termos como "revolução" e "insurreição" e as metamorfoses factíveis a partir do "grau de aderência" que certas opiniões obtêm. Assim, Fonseca se preocupara em tomar medidas de precaução pela novidade daquelas ideias na região e seus possíveis efeitos numa província com uma "opinião pública tão imatura". A seu favor, Costa Soares lembrou que nenhuma prisão ou repreensão foi motivada por demonstrações de apoio ao governo do Grão-Pará e que, nos três meses que separaram a "adesão" das duas províncias ao movimento do Porto, suas relações comerciais se mantiveram intactas. Ainda sobre a "imaturidade da opinião pública" no Maranhão, Costa Soares reiterou que a permanência de Fonseca à frente do governo também se devia ao estágio inicial de desenvolvimento do espírito público na província - tarefa para qual o jornal se habilitava -, quadro que oferecia riscos de uma "dissensão cívica".

Os folhetos também questionaram a legitimidade das "200 assinaturas" que sustentaram a manutenção de Pinto da Fonseca à frente do governo, numa província que contava mais de 100.000 habitantes. A resposta de Costa Soares a esse argumento reforça certa percepção de opinião pública delineada pelo Conciliador:

Não sabem eles que essa totalidade é de toda a província, e que os 200 (suponhamos) são habitantes da cidade capital? Esqueceram-se que a maior parte destes mesmos habitantes são pessoas de condição obscura, que vivem no esquecimento, no ócio, na apatia de sentimentos, lenhados a

ainda afirmou que Antonio José Meirelles foi o responsável pelas despesas com as homenagens, mas que os convites foram feitos pelo bispo Nazaré, com o intuito de disfarçar o favor de Meirelles a Fonseca.

${ }^{35}$ Conciliador, suplemento ao no $56,23 / 1 / 1822$, p. 2. 
uma existência pouco diferente da dos troncos, e que não têm expressão pública? Desconhecem acaso, que em tais ocasiões somente têm ingerência indivíduos conhecidos por sua representação, emprego, e estabelecimentos; e que 200 pessoas destas classes constituem uma absoluta maioria, em quase generalidade dos cidadãos do Maranhão? ${ }^{36}$

Fonseca possuía a maioria entre os cidadãos "ativos, iluminados e com estabelecimento", expressão da opinião pública ludovicense (São Luís), que se estendia / impunha a todo o Maranhão. De maneira arguciosa, Costa Soares devolveu a dúvida sobre a legitimidade de uma opinião sustentada em pequeno número de assinaturas, referindo-se a uma representação de 56 cidadãos que encaminharam ao rei e ao Soberano Congresso denúncias contra o governo:

(...) que pretendem provar os seus acusadores com cinqüenta e seis assinaturas postas no caviloso, mentiroso, injurioso, faccioso, insidioso, escandaloso, aleivoso, furioso, manhoso, tenebroso, venenoso, vertiginoso monstruoso e asqueroso requerimento feito às Cortes? Podem acaso encobrir que a maior parte dessas mesmas assinaturas foram alcançadas com dolo e com suborno vil? ${ }^{37}$

Adjetivações à parte, o trecho acima explicita a linha de defesa assumida pelo jornal, fundamentada na desqualificação dos publicistas e dos cidadãos que representaram contra a administração de Fonseca. Já nas primeiras respostas, o Conciliador atribuiu o financiamento dos folhetos que "sujavam as tipografias de Lisboa" a Honório José Teixeira, responsável pelo sustento desses autores em Portugal ${ }^{38}$. Teixeira também estaria ligado às representações encaminhadas ao Soberano Congresso: um dos deputados maranhenses nas Cortes, o desembargador Joaquim Antonio Vieira Belford, foi acusado pelo major Rodrigo Pinto Pizarro de ser "escravo assalariado" de Teixeira ${ }^{39}$. Teixeira foi preso em abril de 1821 e liberado dias depois. Sua atuação parece estar no cerne das cisões políticas que movimentaram o Maranhão naqueles meses ${ }^{40}$.

Honório era filho do comendador Caetano José Teixeira, um dos principais comerciantes de escravos, importante credor do erário e representante do Banco do Brasil no Maranhão. Com a morte do pai, em 1818, teve dificuldades com a administração do que herdara, perdendo espaço para Meirelles tanto no comércio de escravos quanto

\footnotetext{
${ }^{36}$ Conciliador, suplemento ao nำ62, 14/2/1822, p. 4.

37 Ibidem.

${ }^{38}$ Conciliador, suplemento ao no 46, 20/12/1821.

${ }^{39} \mathrm{O}$ irmão do deputado, José Joaquim Vieira Belford, era cunhado de Honório José Teixeira. Para as acusações, ver Conciliador nํ 66, 27/2/1822, p. 4.

${ }^{40}$ Em carta de 16 de abril de 1821, publicada por Hum maranhense no Diário do Governo do Rio de Janeiro, localizei a primeira referência a Honório José Teixeira como principal opositor à permanência de Fonseca no governo do Maranhão. Diário do Governo, no 71, 14/8/1821, p. 204.
} 
nos negócios públicos. As possibilidades abertas pelo movimento constitucional do Porto permitiram-Ihe uma intensa atuação no cenário político maranhense, com ecos em Lisboa e Londres. Por essa razão, tornou-se o alvo preferido do Conciliador, que dedicou espaços generosos a Teixeira, personificação dos "facciosos" que desejavam abalar a nova ordem constitucional.

Com ironia, o jornal estranhava o fato de Teixeira, um rapaz educado em Londres, responder a mais de oitenta processos ${ }^{41}$, entre dívidas, falsificação de assinaturas e brigas dentro do Teatro. O "constitucionalismo ocasional" de Teixeira também foi lembrado pelo jornal, que registrou o fato de as suas janelas não estarem iluminadas no aniversário de dois anos da Revolução do Porto, atitude estranha a um "verdadeiro

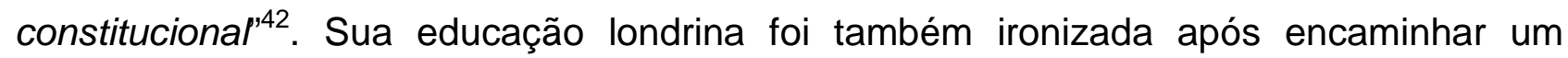
requerimento a Pinto da Fonseca, com base nos princípios de regulamentação da liberdade de imprensa, pedindo, sem sucesso, que um júri analisasse a conduta do jornal, por transcrever trechos do periódico português Liberal que lhe teriam sido ofensivos ${ }^{43}$. $\mathrm{O}$ Conciliador sugeriu a Teixeira que o tribunal dos jurados fosse substituído pelo tribunal da opinião pública, desafiando-o no campo do debate político, prática mais condizente a um "Constitucional, liberal, educado na Inglaterra". Os redatores salientaram que a Tipografia sempre estivera à disposição, mas que alguns publicistas preferiam Londres - referência ao $C B$ - a São Luís, como forma de dificultar a refutação dos disparates publicados ${ }^{44}$.

Talvez a Tipografia não estivesse tão disponível assim. Na edição nำ 52 , o jornal respondeu à acusação de Honório Teixeira, que teria chamado o Conciliador de "mercenário do governo e monopolizador da tipografia", em alusão à recusa em imprimir um novo periódico: tratava-se da Gazeta da Verdade, sob a responsabilidade do médico Manoel Rodrigues de Oliveira ${ }^{45}$. A direção da Tipografia alegou, "sobrecarga de trabalho e

\footnotetext{
${ }^{41}$ A maioria desses processos dizia respeito a conflitos motivados pela herança deixada por seu pai. 0 Conciliador fez referência a "parentes, sócios, correspondentes, credores, devedores". Conciliador, 끄 51, 5/1/1822, p. 5-6.

${ }^{42}$ Conciliador, no $118,28 / 8 / 1822$, p. 5 .

${ }^{43}$ Conciliador, suplemento ao no $46,20 / 12 / 1821$, p. 1-3.

${ }_{44}^{4}$ Conciliador, № 64, 20/2/1822, p. 5.

${ }^{45}$ Nascido em Portugal, Manoel Rodrigues de Oliveira terminou seus estudos em Coimbra em 1799, tendo chegado ao Maranhão em 1804 ou 1805. Exerceu as funções de físico-mor e cirurgião-mor do reino, além de médico do Hospital Militar do Maranhão. Faleceu em São Luís no ano de 1826. Ver: Marques, César Augusto (2008). Dicionário histórico-geográfico da província do Maranhão. 3 ed. São Luís: Edições AML, 2008, p. 740. Oliveira foi um dos abaixo-assinados do Protesto... e do Requerimento..., encaminhados ao Soberano Congresso com críticas à administração provincial, e redigiu a Folha Medicinal, questões que tratarei adiante.
} 
aumento dos custos de produção,46, argumentos que indignaram Oliveira. De modo "prestativo", o Conciliador se ofereceu para publicar artigos endereçados ao novo jornal ${ }^{47}$. Curiosamente, o controle do acesso à Tipografia Nacional do Maranhão deu mais visibilidade às demandas que, impressas do outro lado do Atlântico, atingiram um público muito maior. Além de Lisboa, Londres e Liverpool tomaram contato com as "novidades" do Maranhão. Em fevereiro de 1822, o Conciliador acusou Hipólito da Costa de receber de um "certo ricaço do Maranhão boa porção de dinheiro para dizer bem dele e chamar pela independência ou desunião do Brasil"48. O "certo ricaço", Honório Teixeira, esteve no centro das principais considerações feitas pelo $C B$ sobre a movimentação política no Maranhão.

Desde junho de $1821^{49}$, momento em que os primeiros expulsos do Maranhão chegaram à Europa, o $C B$ manifestou sua preocupação com as medidas de segurança tomadas por Fonseca, a partir de abril daquele ano. Ainda cauteloso, Hipólito observou que pessoas foram "presas por opinião", mas que aguardaria a chegada de mais notícias para avaliar sua permanência à frente da província e seus possíveis efeitos. Amistosamente, o Conciliador atribuiu as primeiras considerações de Hipólito a informações equivocadas, transmitidas por "emissários da discórdia", com o objetivo de desqualificar a "cívica decisão de punir os anarquistas" e manter Fonseca, livrando o Maranhão de "facções e partidos vingativos num momento de entusiasmo" 50 .

Gradativamente, os dois jornais subiram o tom. Hipólito classificou como "infeliz" a decisão de manter Fonseca no governo, opinião sustentada no conhecido desprezo que o redator nutria pelos governadores do reino, mas também pelo ordenamento de prisões, deportações e devassas sem formação de processo e à revelia - ou com a condescendência - do Tribunal da Relação, caracterizando o que Hipólito, ironicamente,

\footnotetext{
${ }^{46}$ Conciliador, № 52, 9/1/1822. É importante frisar que, dias antes, a Tipografia concedeu um desconto de $25 \%$ para a impressão do Conciliador. Ver: Sousa, José Leandro da Silva. Concessão de $25 \%$ de desconto para imprimir o Conciliador (23/12/1821). Biblioteca Pública Benedito Leite (BPBL). Seção de Manuscritos, 239 (245) M1 G2 E9.

${ }^{47}$ Nas edições no 52,53 e 55, o jornal anunciou a disponibilidade em publicar artigos endereçados à Gazeta da Verdade. Esse espaço só foi efetivamente ocupado na edição oㅡ 68,6/3/1822, com a publicação de duras críticas à finda administração de Pinto da Fonseca, assinadas por Manuel Raimundo Correia de Faria - vereador na primeira Câmara eleita no pós-Independência - e refutadas por Costa Soares na edição seguinte. A pressão para a circulação de outro jornal parece ter resultado na publicação, a partir do mesmo mês de março, da Folha Medicinal.

${ }^{48}$ Conciliador, no 95, 8/6/1822, p. 4. O jornal utilizou como recurso a transcrição do no 24 das Reflexões do Padre Amaro, que, por intermédio de um diálogo, enumerou uma série de acusações contra Hipólito, dentre as quais a transcrita acima.

${ }^{49} C B$, no 157, junho de 1821, p. 669-670.

${ }^{50}$ Conciliador, ํㅡ 40, 28/11/1821, p. 7.
} 
definiu como práticas de um "Governo Constitucional à portuguesa" eram conhecidas e levaram a sessão das Cortes de 2 de outubro de 1821 à decisão de advertir Fonseca por "arrogar a si as atribuições do poder judiciário (...) a soltar uns e a exterminar outros, sem que estes fossem ouvidos em sua defesa" ${ }^{22}$. A decisão das Cortes de apenas advertir Fonseca irritou Hipólito, para quem a fragilidade das acusações e a intenção das prisões ficavam evidentes com o resultado da devassa, que inocentou os principais envolvidos, inclusive Honório Teixeira.

Sobre o Conciliador, o redator do $C B$ lamentou o fato de o periódico se prestar ao papel de elogiar desmesuradamente o governo e insultar seus inimigos políticos, que não tinham a quem recorrer. Prova disso era a recusa ao pedido de reparo feito por Teixeira, contra ataques publicados pelo jornal.

O Conciliador insistiu na tese dos "sermões encomendados" por Teixeira ao CB, que continham acusações também impressas em Portugal a mando do mesmo "mecenas", reduzindo a questão a uma oposição sistemática, coordenada e financiada por Honório Teixeira.

Os argumentos desenvolvidos nos folhetos portugueses - e transcritos ou reformulados pelo $C B$ - foram refutados pelo Conciliador, na maioria das vezes, em textos assinados por Costa Soares. Em meio às farpas trocadas de lado a lado, Costa Soares não esqueceu de apresentar esses autores como "comerciantes falidos", "incitadores de escravos", "pretos" e "mercenários", que viram no momento político a possibilidade de obter algum tipo de vantagem. Exageros e ofensas à parte, o momento parecia mesmo propício para se clamar por mudanças.

O comerciante Manoel Pereira de Carvalho deixou o Maranhão em 20 de junho de 1821, alegando perseguições políticas que teriam trazido prejuízo aos seus negócios e culminado com uma ação de despejo, que expusera sua mulher e filhos a privações. Sua condição econômica serviu de base para as ponderações de Costa Soares, que o definiu como um cidadão sem peso político, por não possuir "armas, letras ou riquezas". Para o autor, Carvalho aproveitou o momento político para se livrar das dívidas - primeiro, à

\footnotetext{
${ }^{51}$ Na edição no 164 , de janeiro de 1822, p. 75-80, o CB reproduziu a ordem de prisão contra Honório José Teixeira, de 15 de abril de 1821, e a portaria de 17 de abril que ordenou a devassa fundamentada na "opinião pública" e na "notória conduta insidiosa" de cidadãos como Honório José Teixeira. Transcreveu ainda a portaria de 25 de junho de 1821, em que Fonseca apresentou os primeiros resultados da devassa, que terminou por inocentar os acusados pela falta de "prova plena e cabal". O objetivo da reprodução desses documentos era evidenciar as motivações políticas das medidas tomadas por Fonseca em abril de 1821, sustentadas em práticas características do Antigo Regime, típicas dos governadores das províncias portuguesas.

${ }^{52}$ Ibidem, p. 64-65.
} 
espreita de mudanças não ocorridas em abril de 1821; depois, incitando a revolução por meio de impressos, aproximando-se dos "Martins de lá". Essa última referência é uma provável alusão ao comerciante Domingos José Martins, que atuou na cena política pernambucana entre 1817 e 1824. Martins estimulou a organização de regimentos compostos apenas por negros, no caminho de uma efetiva sublevação ${ }^{53}$. Guardadas as devidas proporções entre a intensidade dos conflitos em Pernambuco e no Maranhão, mas considerando aqui as intenções de Costa Soares, a imagem de Manoel Carvalho como um "Martins" Ihe permitiu desqualificar as críticas à situação política da província, já que formuladas por "negros", "libertos" e "simpatizantes".

Sobre outro "incitador de escravos", José de Loureiro Mesquita, Costa Soares argumentou que não fora punido ${ }^{54}$ por crime de opinião, conforme publicado no $C B^{55}$, mas por sua conduta. Pesava sobre ele um processo relativo ao período em que ocupou 0 cargo de Ouvidor Geral do Crime, no Piauí, de onde foi expulso em 1814. Além de "depredação da Fazenda Real', Mesquita foi acusado de armar escravos na cidade de Oeiras, processo que ainda transcorria. Em abril de 1821, foi preso juntamente com Honório Teixeira, acusados de incitarem escravos, dessa vez no Maranhão, com o objetivo de depor Pinto da Fonseca.

A preocupação com os escravos e libertos era latente numa sociedade em que representavam $77,8 \%$ da população ${ }^{56}$. Tomado ao pé da letra ou como mecanismo de demonização dos adversários políticos, o risco de um levante escravo paira sobre os registros do período ${ }^{57}$. Manoel Paixão dos Santos Zacheo ${ }^{58}$ denunciou a farsa de um levante escravo concatenado pelos opositores de Fonseca, igualmente proprietários de

\footnotetext{
${ }^{53}$ Mota, Carlos Guilherme. Nordeste 1817: estruturas e argumentos, São Paulo: Perspectiva, 1972, p. 52, definiu-o como "jacobino rústico".

${ }^{54}$ Após ser deportado, Mesquita nomeou Honório José Teixeira como seu procurador. Ver: Conciliador, suplemento ao $\mathrm{n}^{\circ} 47,24 / 12 / 1821$, p. 2.

${ }_{55} C B$, no 157 , junho de 1821, p. 669-670.

${ }^{56}$ Lago, Antonio Bernardino Pereira do (2001). Estatística histórico-geográfica da Província do Maranhão, São Paulo: Siciliano, p. 87-89.

57 O que parece comum às "cidades negras" do Brasil oitocentista. Para o Rio de Janeiro, Moreira, Carlos Eduardo de Araújo (et al.) Cidades negras: africanos, crioulos e espaços urbanos no Brasil escravista do século XIX. São Paulo: Alameda, 2006, p. 52, observou uma intensa correspondência, além de matérias publicadas em jornais, sobre o medo de levantes escravos. Ainda que por vezes inexistentes, pretexto para o aumento da repressão, os potenciais levantes compuseram o cenário dessas cidades.

${ }_{58}$ Advogado e proprietário de terras, foi um dos principais publicistas do período, com a autoria de, pelo menos, sete folhetos. Fugiu do Maranhão em agosto de 1821, após Fonseca ordenar sua prisão. Para um ensaio biográfico sobre o personagem, ver Costa, Yuri e Galves, Marcelo Cheche (2011) O Epaminondas Americano: trajetórias de um advogado português na Província do Maranhão, São Luís: Café e Lápis, Editora UEMA.
} 
escravos, como artifício utilizado pelo governo para justificar as prisões e deportações ${ }^{59}$. Mas não foi apenas a instrumentalização dessa população escrava, hipoteticamente levada adiante por grandes proprietários de escravos, como Honório José Teixeira, que preocupou as autoridades: parte dessa população atribuiu sentidos próprios às noções de "mudança" e "liberdade".

$\mathrm{Na}$ devassa instaurada após os episódios de abril de 1821, testemunhas afirmaram ter visto dois pretos tocando viola, um dos quais teria dito: "Deixa estar, parceiro, que amanhã é o último dia,60. Cantos de sedição também provocaram prisões em $1822^{61}$. A partir da referida devassa, lara Lis F. S. Carvalho Souza ${ }^{62}$ recuperou testemunhos que falavam em pasquins afixados no prédio da Alfândega, prometendo liberdade aos escravos, com títulos como "Às armas pretos ou à vossa liberdade" e "Viva Loureiro, e morram os brancos, e cá fica o dinheiro":

Disseminava-se assim a apreensão em meio às elites de que uma nova São Domingos se repetisse. Comparação, aliás, que aparece nas falas das próprias testemunhas. O depoente tenente-coronel Manoel de Souza Pinto, de 26 anos, contou que ouvira uns pretos de Antonio José de Souza andavam falando, naqueles dias, de São Domingos. Ao serem inquiridos pelo senhor, responderam, ambiguamente, que tratavam de um amigo chamado São Domingos, o que não atenuava o temor senhorial ou esclarecia o dito ${ }^{63}$.

Proibidos ou não, escravos, libertos e brancos pobres "estavam na praça" e viveram esse momento de ampliação dos espaços da política, preocupando as autoridades e explicitando os receios de publicistas como Costa Soares, que por diversas vezes aproximou as "desordens" provocadas pelos "facciosos" e pela "populaça", por vezes, indissociando-as.

Também incomodava o redator a presença de libertos nos folhetos e abaixoassinados, espaços de representação política reservados aos letrados e invadidos, agora, por ex-escravos, gente incompatível, acreditava, com os parâmetros civilizatórios

\footnotetext{
59 Zacheo, Manoel Paixão dos Santos (1822). Ao Soberano Congresso Nacional, nas Cortes Gerais Extraordinárias e Constituintes da Nação Portuguesa. O Epaminondas Americano sobre a Revolução do Maranhão, Lisboa: J. B. Miranda, Biblioteca do Itamaraty.

${ }^{60}$ Afirmação recolhida junto à $35^{a}$ testemunha da devassa aberta no Maranhão em 1821. ANTT Arquivo do Ministério dos Negócios Eclesiásticos e da Justiça, maço 102, no 1 apud Souza, lara Lis Franco Schiavinatto Carvalho (1999). Pátria coroada: o Brasil como corpo político autônomo (1780-1831), São Paulo: UNESP, p. 151.

${ }^{61}$ Relação dos réus sentenciados no Maranhão em 1822, publicada no Conciliador, no 160, 22/1/1823, p. 4.

62 As demais considerações da autora sobre a devassa também tiveram como referência o Arquivo do Ministério dos Negócios Eclesiásticos e da Justiça, maço 102, no 1, localizado no Arquivo Nacional da Torre do Tombo. Op. cit.

${ }^{63}$ Souza (1999). Op. cit., p. 152.
} 
vigentes. Curiosamente, recorreu ao argumento da origem desses pretensos cidadãos lembro, em sentido diametralmente oposto àquele em que distinguiu Pinto da Fonseca de sua origem.

Entre a "populaça", chama a atenção o caso de Pedro Antonio do Nascimento, o "Pai Pedro". Na edição de 19 de janeiro de 1822, o jornal publicou uma carta de Gonsallo José do Nascimento, seu irmão, em que afirmava ser Pedro livre e pago por Manoel Carvalho e José de Loureiro Mesquita, a mando de Honório Teixeira - tratado pelo jornal como "Zimbório Guiné" Teixeira. Degredado para o Rio Negro em 1820, Pedro parece ter chegado a Lisboa no mesmo ano, exercendo uma série de ofícios antes de sua aparição na cena pública.

O fato de Pedro não pertencer à "gente branca" levou Costa Soares a fazer referências a ele apenas em notas de rodapé, lugar adequado para um "Quixote da cafraria" - alusão à senzala, "berço" de Pedro. Ainda nesse sentido, lembrou que Pedro "estudou humanidades nas calcetas", menção a algumas penas que já havia cumprido. Ex-escravo, ex-preso e sem estudo, a atuação de Pedro Antonio do Nascimento irritou particularmente Costa Soares, que ainda alertou para o fato de Pedro representar outros "semibrancos do Maranhão". Com pesar, admitiu que as "negras penadas" do autor foram fixadas nas esquinas de Lisboa e de São Luís, "parvoíces" repetidas nas praças, ruas e lojas e sustentadas por "assinaturas compradas, mendigadas ou extorquidas" e encaminhadas ao Soberano Congresso ${ }^{64}$.

As acusações de Costa Soares deixam transparecer a articulação entre os folhetos produzidos em Lisboa e os abaixo-assinados que corriam por São Luís. O Protesto de lealdade e reconhecimento do povo ao Rei - analisado adiante, foi encaminhado ao Soberano Congresso com data de 18 de dezembro de 1821, momento em que os primeiros folhetos circulavam pela cidade.

Escrever e assinar eram duas formas de se fazer representar que preocupavam os redatores e colaboradores do Conciliador. A publicização dos motivos que levariam os cidadãos a compor um abaixo-assinado contrário ao governo de Fonseca: "distração", "coação", "suborno", "falta de caráter" ou "interesses políticos" incutiam formas - quase sempre desairosas - de estar na política. Antes de se despedir do Maranhão, no final de fevereiro de 1822, Rodrigo Pinto Pizarro e João Pinto de Sousa Coutinho, ajudantes de

${ }^{64}$ Conciliador, suplemento ao ํㅜ 56, 23/1/1822. 
ordens de Fonseca, afirmaram ${ }^{65}$ que a maioria dos que assinaram e encaminharam ao rei e ao Soberano Congresso o Protesto... eram "filhos de mãe desconhecida". Em meio a diatribes disparadas contra "crioulinhos forros" 66 , "comerciantes falidos" e "maridos traídos", Pizarro e Coutinho reconheciam que a presença dos brigadeiros Manuel Antonio Falcão e Manuel José Palmeirim no abaixo-assinado se devia ao fato de terem sido afastados do comando militar por Fonseca, o que trouxe instabilidade às tropas, e que Miguel Ignácio dos Santos Bruce assinara o documento por desejar "ser independente". Ainda que sem maiores explicações sobre o que significava "ser independente", é importante salientar que Miguel Bruce esteve à frente do primeiro governo, após a Independência.

Sem minimizar o problema relacionado às tropas e a importância da atuação de Miguel Bruce, questões tratadas a seguir, vale destacar a heterogeneidade do dissenso, provocado por razões das mais diversas e nem sempre apreensíveis: de Manoel Rodrigues de Oliveira, demitido de suas funções no Hospital Militar e ainda sob o efeito da "sobrecarga de trabalho" alegada pela direção da Tipografia para a não impressão da sua Gazeta da Verdade ${ }^{67}$, até Honório José Teixeira, as motivações dos abaixo-assinados não oferecem um quadro seguro, derivado de grupos homogêneos, embora seus propósitos convergissem para a demissão de Fonseca e a reorganização da política provincial, demandas revestidas com o constitucionalismo português, em voga. A seguir, uma tabela com nome e ocupação dos 65 cidadãos que compuseram o Protesto...:

\section{TABELA 1 - Nome e ocupação declarada pelos assinantes do Protesto de lealdade e reconhecimento do povo ao Rei.}

\begin{tabular}{|l|l|}
\hline \multicolumn{1}{|c|}{ Nome } & \multicolumn{1}{c|}{ Ocupação declarada $^{\text {68 }}$} \\
\hline 1 - Luís Maria da Luz e Sá & arcipreste, presidente do cabido \\
\hline 2 - Maurício José Berredo de Lacerda & cônego, advogado do Tribunal da Relação \\
\hline 3 - Joaquim Antonio da Cunha & ajudante de ordens \\
\hline 4 - Agostinho Raymundo dos Reys & * \\
\hline 5 - Manoel José Xavier Palmeirim & brigadeiro \\
\hline 6 - Manoel Antonio Falcão & brigadeiro chefe do regimento de linha \\
\hline 7 - Miguel Ignácio dos Santos Freire e Bruce & capitão reformado de milícia, advogado do \\
\hline
\end{tabular}

${ }^{65}$ Carta de Rodrigo Pinto Pizarro em 17 de fevereiro de 1822 e Carta de João Pinto de Sousa Coutinho, publicadas no Conciliador, no 65, 23/2/1822, p. 2-5.

${ }^{66}$ Forma como se referiram a Valério Lopes e a Raymundo José Bruce, ambos assinantes do Protesto....

${ }^{67}$ Posteriormente, já como redator da Folha Medicinal, Oliveira afirmou que foi demitido do posto de médico do Hospital Militar por ter votado a favor de uma Junta de Governo, em abril de 1821. Folha Medicinal, no 9 , 6/5/1822, p. $70-72$.

68 * Não declaradas. 


\begin{tabular}{|c|c|}
\hline & Tribunal da Relação \\
\hline 8 - Francisco do Valle Porto & tenente coronel \\
\hline 9 - Manuel José de Medeiros & proprietário \\
\hline 10 - João Rodrigues de Miranda & negociante \\
\hline 11 - Antonio Marques Rodrigues & * \\
\hline 12 - Manoel Caetano da Fonseca & secretário \\
\hline 13 - José Francisco de Magalhães & negociante \\
\hline 14 - Manoel Caetano de Carvalho & * \\
\hline 15 - José Joaquim Carvalho de Aragão & tenente coronel de milícias \\
\hline 16 - Valério Correia Lopes & * \\
\hline 17 - Joaquim da Costa Barradas & guarda mor do Tribunal da Relação \\
\hline 18 - José Antonio da Silva & * \\
\hline 19 - José Antonio de Freitas & capitão \\
\hline 20 - Domingos Rodrigues de Miranda & capitão de milícias \\
\hline 21 - João Dias Monteiro & tenente do regimento de milícias da cidade \\
\hline 22 - Domingos Antonio de Oliveira & negociante \\
\hline 23 - João José do Rego & militar \\
\hline 24 - Francisco Felix da Fonseca Pereira e Pinto & alferes do regimento de linha \\
\hline 25 - Diogo Sarmento da Maia & alferes \\
\hline 26 - Carlos Caetano de Miranda Vasconcelos & tenente \\
\hline 27 - Antonio José Rabello & alferes \\
\hline 28 - Antonio Benedito Bernardes & capitão do regimento de linha \\
\hline 29 - Manuel Raymundo Pereira & advogado \\
\hline 30 - Honório José Teixeira & coronel do regimento de milícias \\
\hline 31 - Manuel Caetano de Lemos & conselheiro da Mesa da Estiva \\
\hline 32 - José Antonio Soares de Sousa & médico \\
\hline 33 - José Lopes de Lemos & militar \\
\hline 34 - Manoel Rodrigues de Oliveira & médico do hospital militar \\
\hline 35 - Joaquim [...] de Carvalho & Tribunal da Relação \\
\hline 36 - José Cursino da Silva Raposo & tenente coronel de milícias \\
\hline 37 - Raymundo José Bruce & * \\
\hline 38 - Domingos Lourenço & * \\
\hline 39 - Custódio do Valle Porto & * \\
\hline 40 - José Raymundo Carneiro Junqueira & capitão do regimento \\
\hline 41 - José Francisco Gonçalves da Silva & capitão de milícias \\
\hline 42 - Joaquim Seixas Corrêa & funcionário público \\
\hline 43 - Manuel Cândido Castro & * \\
\hline 44 - José Joaquim Rodrigues Lopes & * \\
\hline 45 - [...] João Antonio Velloso & * \\
\hline
\end{tabular}




\begin{tabular}{|c|c|}
\hline 46 - José de Azevedo Freitas & * \\
\hline 47 - Custódio José das [...] & negociante \\
\hline 48 - Manuel Antonio Antunes Correia & conselheiro $[\ldots]$ \\
\hline 49 - Luiz da Fonseca & cônego \\
\hline 50 - Bernardo Pereira de Berredo & capitão do regimento de milícias \\
\hline 51 - Antonio Joaquim Moreira & negociante \\
\hline 52 - Manuel Gabriel [...] & * \\
\hline 53 - Izidoro Rodrigues Pereira & coronel reformado \\
\hline 54 - Antonio Teixeira C. Gonçalves & * \\
\hline 55 - Manuel [...] Ramos & alferes do regimento de milícias da cidade \\
\hline 56 - José do Carmo e Figueiredo & * \\
\hline 57 - Joaquim de $[\ldots]$ & negociante \\
\hline 58 - Antonio Correia d'Aguiar & negociante \\
\hline 59 - João Rodrigues [...] & * \\
\hline 60 - Miguel José Negreiros Guimarães & * \\
\hline 61 - João José [...] & * \\
\hline 62 - Miguel Lamagner [...] & * \\
\hline 63 - Domingos Cadavilla Velloso & * \\
\hline 64 - José Jansen Lima & * \\
\hline 65 - José Joaquim Vieira Belford & comandante do $1^{0}$ regimento de milícias \\
\hline
\end{tabular}

* Ocupação não declarada

Fonte: IHGB, lata 400, documento 10

Em comum a uma parcela importante dos abaixo-assinados, os desdobramentos provocados pelo abril de 1821: entre os 8 votos favoráveis à Junta de Governo, dados naquele mês, 7 foram de cidadãos que, agora, representavam contra o governo ${ }^{69}$; escrevendo em junho de 1821, portanto, alguns meses antes do Protesto..., José de Loureiro Mesquita fez referência ao envolvimento de, pelo menos, 7 outros abaixo$\operatorname{assinados}^{70}$ nas disputas que se seguiram à "adesão". Tais permanências demarcam, sobremaneira, o momento da "adesão" como potencializador das divergências políticas provinciais, porém, explicar a contento as variadas razões para o dissenso, exercício praticado a seguir, não é tarefa das mais fáceis.

\footnotetext{
${ }^{69}$ São eles: Manoel Rodrigues Oliveira, Miguel Bruce, Miguel Lamagner, João Rodrigues de Miranda e Bernardo Pereira de Berredo. Outros dois cidadãos, Manoel Pereira de Carvalho e José Antonio de Freitas, compuseram o Requerimento..., abaixo-assinado apresentado a seguir. O único entre os 8 eleitores contrários a Fonseca que não compôs abaixo-assinados foi Manoel Paixão dos Santos Zacheo, à época, refugiado na província do Grão-Pará.

${ }^{70}$ A saber: Manoel José Xavier Palmeirim, Manoel Antonio Falcão, João Rodrigues de Miranda, Antonio Marques Rodrigues, José Joaquim Carvalho de Aragão, Honório José Teixeira e José Joaquim Vieira Belford. Mesquita (1822). Op. cit.
} 
Sobre as tropas, o Protesto... contou com a assinatura de militares do primeiro escalão, como os brigadeiros Falcão e Palmeirim e os tenentes Monteiro e Aragão, nomes que não constaram da petição citada por Fonseca ${ }^{71}$, documento que teria fornecido o primeiro suporte para a "adesão", como já salientado. De "espírito constitucional', esses militares teriam resistido a todo tipo de pressão e recusado um aumento na tabela de soldos ${ }^{72}$, anunciado em 13 de abril, segundo Mesquita, em troca de servilismo, forma como Fonseca concebia a noção de ordem. Por tais razões, teriam sido demitidos, presos e /ou deportados ${ }^{73}$.

Honório José Teixeira, outro abaixo-assinado citado por Mesquita, também foi preso. Já salientei a importância de Teixeira para os debates do momento e suas desavenças com Meirelles, questão retomada adiante. Aqui, apenas reitero a importância das razões comerciais para as disputas em curso: entre os 7 cidadãos - cujos nomes completos permitiram a identificação - que assinaram o Protesto... como "proprietários" ou "negociantes", apenas Domingos Antonio de Oliveira pertencia ao Corpo de Comércio e Agricultura. Um desses negociantes, João Rodrigues de Miranda, afirmou ser perseguido por Meirelles desde o tempo em que ocupou o cargo de almotacé, quando teria obstado algumas manobras do negociante ${ }^{74}$. Some-se aos "negociantes de oposição", não vinculados ao Corpo de Comércio e Agricultura, o nome de dois cidadãos que preferiram assinar como "militares", Izidoro Rodrigues Pereira e o próprio Honório Teixeira, e o de Custódio Valle Porto, que não identificou a sua ocupação. Outro negociante abaixoassinado, Francisco do Valle Porto, era membro do Corpo de Comércio e Agricultura, mas assinou como "tenente coronel", talvez com o objetivo de não vincular seu nome àquele agrupamento sob forte influência de Meirelles.

Mais heterogêneo, contudo, era o grupo de, pelo menos, 10 abaixo-assinados, ligados a Miguel Bruce. Personagem de relevo no pós-Independência, Bruce era um velho conhecido da política provincial. Vereador em 1804, compôs o governo de José Tomás de Menezes (1809-1811) e participou do governo interino formado antes da posse de Paulo José da Silva Gama, em 1811. No mesmo ano, foi preso, acusado de vários crimes, entre

\footnotetext{
${ }^{71}$ Entre os 25 militares da petição, apenas Carlos Caetano de Miranda Vasconcelos também assinou o Protesto...

${ }^{72} \mathrm{Na}$ verdade, a nova tabela dobrava o valor dos soldos. Ver: Folha Medicinal, no 3, 25/3/1822, p. 19. Como parte das pressões, Mesquita ainda teria recebido a cobrança e, depois, uma proposta de perdão, referente a uma dívida que possuía junto aos cofres públicos. Mesquita (1821). Op. cit., p. 14.

${ }^{73} \mathrm{O}$ brigadeiro Falcão foi apenas afastado. Ibidem, p. 5.

74 Outro abaixo-assinado, José Jansen Lima, foi almotacé em 1819 e pelas mesmas razões teria caído no desagrado de Meirelles. Tal afirmação consta no artigo assinado O Velho dos Seminários, publicado pelo Argos da Lei, № 30, 19/4/1825, p. 4.
} 
os quais: inquietar o sossego público; organizar reuniões; elaborar e assinar documentos em nome de José Tomás de Menezes; subornar e suspender injustamente funcionários públicos; e elaborar falsas representações ${ }^{75}$. Essas acusações the valeram quatro anos de prisão, entre 1811 e $1815^{76}$. A partir do ambiente de eleições pós-Revolução do Porto, Bruce ocupou lugar de destaque nos processos eleitorais: participou da comissão que tratou das eleições dos deputados maranhenses às Cortes; entrou para o escrutínio nas listas para deputado às mesmas Cortes, tendo sido o único candidato de oposição a Pinto da Fonseca; e foi eleito compromissário e juiz de fato. Com a "adesão" ao Império, em julho de 1823, presidiu as duas primeiras juntas de governo e foi o primeiro presidente da província, nomeado em 1824

Em novembro de 1821, portanto, um mês antes do Protesto..., Bruce escreveu ao rei e às Cortes, pedindo a saída de Fonseca, a demissão de "todo o pessoal dos empregos públicos do Maranhão", e que as tropas fossem compostas apenas por "amantes da Constituição"77. Para além do "despotismo" de Fonseca, a ser extirpado, estavam demandas mais práticas, como o acesso aos empregos públicos e a outras benesses.

Contudo, em que pese a representatividade política de Bruce, antes e após a Independência, tal conexão exige alguns cuidados. A presença de sobrenomes como Barradas, Lemos, Medeiros, Raposo, Rego, Rabello e Fonseca, no abaixo-assinado, na futura administração de Bruce, e nos posteriores processos movidos contra essa administração, sugere certa coesão de um grupo que teria chegado ao poder com a "adesão" ao Império. É preciso salientar, porém, que tal articulação não os promove a um "partido" pró-Independência ${ }^{78}$, gestado desde os episódios decorrentes da Revolução do

\footnotetext{
${ }^{75}$ Para um resumo das acusações enfrentadas por Miguel Bruce, ver Acontecimentos do Maranhão (1810). Bernardo José da Gama. Visconde de Goiana. BN, Seção de Manuscritos, 11, 3,12, p. 10-13.

${ }^{76}$ Para o processo que resultou na prisão de Miguel Bruce, ver Processo movido contra Miguel lgnácio dos Santos Freire e Bruce entre os anos de 1811 e 1813. Arquivo Nacional, Fundo Desembargo do Paço, caixa 161 , pct. 1, doc. 2 . No final de 1815, Bruce já tinha voltado às suas atividades de advogado, como permite entrever o documento Sentenças proferidas em primeira instância, no juízo ordinário da Villa d'Alcântara, Comarca da Cidade de S. Luiz do Maranhão, e em sua confirmação, em segunda, na Relação da mesma Cidade a favor de José da Silva Maya d'Azevedo, e outros RR. Impressas a requerimento de Manoel Francisco Ramos, Commerciante da dita Capitania (1816). Lisboa: Officina de J. F. Monteiro de Campos, Biblioteca Nacional de Portugal (BNP).

77 Ver Carta de Miguel Inácio dos Santos Freire e Bruce ao rei D. João VI, solicitando que a tropa do Maranhão seja constituída por amantes da Constituição. Considera aos antigos governadores do Maranhão déspotas e que a atuação de Bernardo da Silveira Pinto da Fonseca foi vingativa. Solicita ainda a substituição de todo o pessoal dos empregos públicos do Maranhão (1821). São Luís do Maranhão, 9 de novembro de 1821. Arquivo Histórico Ultramarino (AHU), CU 009, cx. 167, doc. 12.183.

${ }^{78}$ Apenas como exemplo, lembro que, pelo menos, 19 desses abaixo-assinados, incluindo os cidadãos ligados a Miguel Bruce, assinaram o Manifesto Constitucional dos Moradores da Cidade de São Luís do Maranhão, em defesa da permanência do Maranhão junto ao Império português. O documento foi elaborado
} 
Porto, o que não os impediu, evidentemente, de ocupar os espaços deixados pela administração deposta com a "adesão".

Outro abaixo-assinado, José Joaquim Vieira Belfort, também esteve entre os eleitos para as duas primeiras juntas no pós-Independência ${ }^{79}$. Velho proprietário da ribeira do Itapecuru, o envolvimento de Belfort com as disputas em curso é peculiar. Cunhado de Honório Teixeira - com o qual, posteriormente, se desentendera ${ }^{80}$, Belfort recém-herdara parte da fortuna do comendador Caetano Teixeira, diversa em propriedades e ramos de atuação. Grande produtor de algodão, sua presença no documento parece mais atrelada aos incômodos provocados pelo poderio acumulado por Meirelles ${ }^{81}$ que por uma oposição entre comerciantes e proprietários, ela mesma, diluída na diversidade das ocupações declaradas.

Tal diversidade, que incluía militares, comerciantes, religiosos, médicos, funcionários da administração, advogados e membros do Tribunal da Relação, expressa a representatividade de uma "opinião pública de oposição", até então ignorada pelo Conciliador:

\section{TABELA 2 - Distribuição das ocupações declaradas pelos cidadãos que assinaram o Protesto de lealdade e reconhecimento do povo ao $\operatorname{Re}^{\beta 2}$.}

\begin{tabular}{|c|c|c|}
\hline Ocupação & Quantidade & $\%$ \\
\hline Militares & 22 & 52,38 \\
\hline Comerciantes & 8 & 19,05 \\
\hline
\end{tabular}

em dezembro de 1822 - momento em que as novidades do Centro-Sul já eram conhecidas no Maranhão, e publicado pelo Conciliador, no 151, 21/12/1822, p. 6-12.

${ }^{79}$ Luís Maria da Luz e Sá e José Lopes de Lemos, também abaixo-assinados, foram eleitos como membros da segunda Junta de Governo, no pós-Independência. Já José Antonio Soares de Souza tornou-se o novo administrador da Tipografia Nacional do Maranhão.

${ }^{80}$ Anos mais tarde, Belfort e Teixeira tornaram-se inimigos ferrenhos, envolvidos em disputas viscerais pela herança do comendador Caetano José Teixeira. Nos requerimentos encaminhados à Corte, no Rio de Janeiro, localizei acusações mútuas de "dilapidação" dessa herança. BN, Seção de Manuscritos, Coleção de Documentos Biográficos - C 383,14 e C 210,020.

81 Em 24 de outubro de 1821, um documento encaminhado ao rei e às Cortes queixava-se dos procedimentos de Meirelles, especialmente quanto às pressões para o recolhimento de assinaturas de apoio a Fonseca. Segundo os autores, Belfort recusara-se a "procedimento tão infame". É de se supor, que os "procedimentos" de Meirelles relacionados à administração pública trouxessem maiores preocupações para Belfort. Ver Representação dos moradores do Maranhão ao rei D. João VI, informando sobre o Estado do Maranhão e solicitando que o governador, o juiz de fora, entre muitos outros sejam substituídos (1821). Maranhão, 24 de outubro de 1821. AHU, CU 009, cx. 167, doc. 12.168.

82 Dos 65 abaixo-assinados, 42 declararam sua ocupação. Para a elaboração da tabela, observei estritamente as ocupações declaradas pelos cidadãos, forma com a qual se apresentaram ao rei e às Cortes. Mesmo em casos como os de Domingos Cadavilla Velloso e Domingos Lourenço, sabidamente, religiosos, mantive a ocupação como "não declarada". 


\begin{tabular}{|c|c|c|}
\hline $\begin{array}{c}\text { Advogados e funcionários } \\
\text { do Tribunal da Relação }\end{array}$ & 6 & 14,29 \\
\hline Religiosos & 2 & 4,76 \\
\hline Funcionários públicos & 2 & 4,76 \\
\hline Médicos & 2 & 4,76 \\
\hline
\end{tabular}

Tratando suas desventuras e demandas a partir do binômio constituição / despotismo, o Protesto... reforçou / atualizou as primeiras críticas publicadas em Lisboa, entre setembro e outubro de 1821, nos folhetos que tomaram como parâmetro a situação da província no primeiro semestre daquele ano.

Em linhas gerais, clamava-se contra o "despotismo", palavra-chave que sustentara as representações ao rei e às Cortes em 28 de agosto $^{83}, 24$ de outubro ${ }^{84}$ e 25 de novembro ${ }^{85}$ de 1821. Como objetivo último, a demissão de Fonseca, "cada vez mais aferrado ao seu sistema anticonstitucionaf'. Se as palavras e as denúncias se repetiam, a novidade agora ficava por conta da notícia trazida por Francisco Alberto Rolim, governador deposto do Ceará, referente à aprovação pelas Cortes de um conjunto de medidas conhecido posteriormente como "Decretos de Outubro", que, entre outras deliberações, estabelecia a eleição de juntas provinciais. Para os autores, as eleições, desde que não influenciadas por Fonseca, abririam a possibilidade de se experimentar, pela primeira vez, as benesses de um governo constitucional. As expectativas por mudanças, motivadas pelo ambiente da "adesão", em abril de 1821, e posteriormente sufocadas, ganhavam novo alento.

Por fim, o documento apontava para as relações nebulosas entre Antonio Meirelles e Pinto da Fonseca. Como já visto, Meirelles teria sido o patrocinador anônimo das exéquias organizadas por ocasião da morte do conde de Amarante, sogro de Fonseca. A pompa da cerimônia, superior à organizada por ocasião do falecimento da rainha Maria I, permitia aos abaixo-assinados dimensionar a influência de Meirelles naquele governo. Outro abaixo-assinado, o Requerimento dirigido ao Soberano Congresso por 48

\footnotetext{
${ }^{83}$ Um trecho dessa representação foi transcrito por Luís Antonio Vieira da Silva e faz alusão ao clima de vigilância e perseguição às opiniões políticas contrárias a Fonseca. Vieira da Silva (1972). Op. cit., p. 55.

${ }^{84}$ Ver Representação dos moradores... (1821). Op. cit.

85 Denúncias contra Fonseca foram lidas nas sessões das Cortes ํo 173, 195 e 264, de 11/9/1821, 2/10/1821 e 24/12/1821, respectivamente, conforme noticiado pelo Conciliador. Também é importante salientar que representações de apoio à permanência de Pinto da Fonseca foram enviadas às Cortes, como a que foi lida na sessão de 15 de fevereiro de 1822, solicitando a dispensa da criação de uma Junta Provincial no Maranhão. Para o extrato dessa sessão, ver Folha Medicinal, nº 6, 15/4/1822, p. 41-42.
} 
habitantes desta cidade ${ }^{86}$, em fevereiro de 1822, tratou mais detidamente do "caso Meirelles".

O Requerimento... foi elaborado uma semana após as eleições para a Junta de Governo do Maranhão, realizadas em fevereiro de 1822. A vitória de nomes como frei Nazaré (presidente) ${ }^{87}$, Filippe de Barros Vasconcellos, João Francisco Leal e Caetano José de Sousa, figuras próximas a Fonseca e Meirelles, assim como a derrota de Miguel Bruce e Izidoro Rodrigues Pereira, nomes que constavam no Protesto... e que assinaram o Requerimento..., parecem ter esgotado, ao menos provisoriamente, as possibilidades de mudanças no quadro político por intermédio de eleições, frustrando as expectativas manifestadas, dois meses antes, no Protesto.... Das 48 assinaturas que compuseram o Requerimento..., $40^{88}$ constaram no Protesto..., sugerindo certa coesão entre os cidadãos que publicamente questionaram a administração de Fonseca e, agora, a Junta que o sucedia. Os procuradores do Requerimento... em Lisboa foram José de Loureiro Mesquita e Manoel Pereira de Carvalho.

Desta feita, os subscritores nominaram mais amplamente aqueles contra os quais se dirigiam, oferecendo novas pistas e reforçando algumas suspeitas quanto às razões para comporem a oposição. Além de Meirelles e Fonseca, o Requerimento... foi dirigido contra os militares Ricardo Coelho e Manoel Pinto de Magalhães - o último, esteve ao lado de Rodrigo Pinto Pizarro na "adesão" ao movimento do Porto; contra o desembargador José Leandro da Silva Sousa - provavelmente, por ocupar agora o cargo de diretor da Tipografia Nacional do Maranhão ${ }^{89}$; e contra o desembargador José Bento da Roxa e Melo, à época presidente da Câmara, que presidira as eleições de 13 de abril. Para Manoel Paixão dos Santos Zacheo ${ }^{90}$, Roxa e Melo foi um dos responsáveis pelas intimidações; ordens de prisão justificadas por boatos sobre um levante escravo;

${ }^{86}$ O Requerimento... foi transcrito pelo Conciliador no suplemento ao № 82, 24/41822.

${ }^{87}$ Nazaré já era o presidente da Junta Consultiva, constituída em 9 de abril de 1821.

88 Entre os 8 novos nomes, pelo menos 2 estiveram com Bruce nas disputas do pós-Independência: Raimundo João Pereira de Cáceres e Albuquerque e Francisco Antonio da Costa Barradas. Os outros 6 abaixo-assinados foram: Manoel Antonio Antunes Cardias, José Antonio da Silva Bastos, José Antonio da Silva, Manoel Pinto Pinheiro, Manoel Antonio Xavier e Joaquim de Azevedo Ramos. Já a Representação dos moradores... contou com 26 assinaturas, 19 das quais iguais às do Protesto... e 15 iguais às do Requerimento...

${ }^{89} \mathrm{Em}$ um abaixo-assinado anterior, datado de 24 de outubro de 1821, 26 cidadãos pediram a demissão dos mesmos nomes, à exceção de José Leandro da Silva Sousa, provavelmente pelo fato de a Tipografia só começar a funcionar em novembro de 1821. Tal hipótese reitera a importância da Tipografia para os debates em curso, e justifica a rápida inclusão de Silva Sousa na lista dos cidadãos a serem demitidos. Ver Representação dos moradores... (1821). Op. cit.

90 Zacheo, Manoel Paixão dos Santos (1822a). Carta do arguelles da província do Maranhão ao Illmo. Exmo Sr. Fco Simões Margiochi. Deputado em Cortes. Lisboa: Na impressão de João Nunes Esteves. BN, Seção de Obras Raras, p. 5. 
deportações e abertura de devassas, "garantindo" a construção da nova ordem constitucional. Noutro folheto ${ }^{91}$, Zacheo o acusou de perseguir ao negociante João Rodrigues de Miranda - abaixo-assinado no Protesto..., Miranda era o arrematador das sizas dos escravos ladinos, atividade prejudicada pela proibição da compra desses escravos, quase sempre vindos de outras regiões da América Portuguesa, a um custo menor. Ainda segundo Zacheo, tal proibição, ordenada por Roxa e Melo, tinha por objetivos beneficiar os grandes importadores de escravos - lembro, uma das principais atividades desenvolvidas por Meirelles - e lesar Miranda.

Basicamente, as denúncias versavam sobre suspensões de cargos públicos, transferências para lugares remotos, prisões injustificadas, manutenção, às expensas do erário, de um "periódico infame", e a prática de contrabando feita sob a proteção do governo provincial, questão que tocava mais diretamente a Meirelles. Aliás, o aprofundamento das acusações contra Meirelles, ensaiadas no Protesto..., ocupou os maiores espaços do Requerimento....

Para os autores, o patrimônio de Meirelles era mais aparente que real, sustentado por juros que recebia da Junta da Fazenda - mesmo tendo dívidas junto a esta, e pelo prestígio político, que lhe valia benefícios indevidos e contratos como o do abastecimento de carne verde ${ }^{92}$, práticas consentidas por "autoridades pervertidas", "prevaricadores" que precisavam ser prontamente substituídos. Colocando-se na condição de "acusadores públicos", portanto sujeitos aos rigores da lei, os abaixo-assinados alegaram não poder anexar documentos comprobatórios de suas afirmações pela dificuldade de acesso aos papéis públicos e pediram que o Soberano Congresso nomeasse uma comissão, composta por membros de fora da província, para apurar as irregularidades. Aqui, o constitucionalismo tomava a forma de transparência nos negócios públicos, bandeira também erguida, a seu modo, pelo Conciliador, que saudava um governo cujos balancetes eram publicados pelo jornal, uma das novidades do tempo.

llegalidades com o erário, perseguições políticas e prática de contrabando fundiram-se nas denúncias sobre a suspensão de Domingos Lopes da Silva e Araújo, guarda-mor da Alfândega, e, tema recorrente, de João Rodrigues de Miranda, exalmotacé, atribuídas à influência política de Meirelles: o primeiro, por impedir o "deliberado

\footnotetext{
91 Zacheo, Manoel Paixão dos Santos (1822b). Os últimos adeoses do Epaminondas Americano ao despotismo. Maranhão: Imprensa Nacional. BNP, p. 17.

92 Há registros da presença de Meirelles no abastecimento de carne verde a partir de 1810, podendo ser anterior. Para 1823, Meirelles perdeu a concorrência para Francisco do Valle Porto, que teria oferecido um preço abaixo do custo para vencê-lo. Sobre as polêmicas em torno do contrato de abastecimento de carne verde para o ano de 1823, ver Conciliador, № 107 (suplemento), 117, 125 (suplemento) e 130.
} 
contrabando organizado por este"; o segundo, por obstruir os interesses de Meirelles, quando exerceu o cargo de almotacé, em 1817. Sobre as rusgas entre Miranda e Meirelles, cabe apenas acrescentar que remontam a um período anterior ao da "adesão", mas tomaram novas proporções a partir dessa, como de resto, as disputas pregressas agora envolvidas na órbita constitucional.

Meirelles foi acusado ainda de receber consignações como correspondente do Banco do Brasil, entre 1818 e 1821, na ordem de 570:000U000 réis e de oferecer, no mesmo período, créditos de apenas 170:000U000 réis, "desaparecendo" com a diferença de 400:000U000, transformada em bilhetes de liquidez duvidosa, dados como garantias de empréstimos contraídos com a Junta da Fazenda e particulares, como Filippe de Barros Vasconcellos, que teria the emprestado 50:000U000 réis, recebendo como hipoteca todos os seus bens.

A resposta de Meirelles ao Requerimento... dá a dimensão não apenas de sua influência sobre o Conciliador, como também da amplitude que os seus negócios atingiam. No suplemento à edição de 24 de abril de 1822, dedicado especialmente ao assunto, o Conciliador publicou o Requerimento..., de pouco mais de duas páginas, como introdução à defesa de Meirelles, que em sete páginas rebateu as acusações e anexou certidões, declarações e balancetes que comprovariam sua inocência.

Em estilo muito semelhante ao utilizado por Costa Soares - quiçá o verdadeiro autor, Meirelles queixou-se pelo fato de o Requerimento... ter sido espalhado pela cidade e das pessoas escondê-lo - talvez por receio de serem obrigadas a entregá-lo ou por medo de serem denunciadas como "anticonstitucionais". Classificou os cidadãos abaixoassinados como "réus de peculato, vadios, pretos degenerados, taberneiros e sapateiros $^{, 03}$. Esses indivíduos, ainda segundo Meirelles, tomaram o cuidado de não colocar suas profissões junto à assinatura como forma de aparecerem perante 0 Soberano Congresso como "homens novos", com valor muito superior ao que realmente tinham ${ }^{94}$. Para o autor, o Requerimento... era obra de Honório José Teixeira, que, no intuito de abalar sua credibilidade mercantil, arregimentou 47 co-assinantes para legitimar

\footnotetext{
${ }^{93}$ Na nota que acompanha a cópia da defesa que Meirelles mandou publicar na imprensa de Lisboa, há a sugestão para a escrita de uma "biografia dos anarquistas do Maranhão", com breves resumos dos defeitos / delitos de 10 abaixo-assinados, quase todos europeus. Já os maranhenses, lembrava, "são pela maior parte mendigos", exceto Honório José Teixeira e Miguel Bruce. Meirelles, Antonio José (1822). Manifesto do Commendador Antonio José Meirelles, da Cidade do Maranhão, desmentindo as monstruosas calúnias que o Bonifácio-mor, Honório José Teixeira, e seus sócios e assalariados levaram à presença do Soberano Congresso, em desabono da sua probidade e crédito mercantil. Lisboa: Typografia de M. P. de Lacerda, BNP, p. 1-2.

${ }_{94}$ Lembro, apenas 23 abaixo-assinados não declararam sua ocupação.
} 
suas acusações ${ }^{95}$. Tais preocupações com a credibilidade mercantil - e também com 0 Soberano Congresso, ainda renderam a impressão de dois folhetos, um em Lisboa, outro em Liverpool, refutando as mesmas acusações.

O "rancor figadal" que Teixeira nutria por Meirelles, segundo este, tinha dois motivos: a ação de Meirelles em abril de 1821 para garantir a permanência de Fonseca no poder; e, anteriormente, o fato de Teixeira não conseguir dar continuidade aos negócios do pai como correspondente do Banco do Brasil no Maranhão, posto ocupado por Meirelles a partir de 1819. Sobre as finanças, Meirelles negou a dívida de 400:000U000 réis junto ao Banco do Brasil, "provando" Ihe ser credor em 808:274 réis. Reconheceu dever pouco mais de 52 contos de réis à Junta da Fazenda, atraso justificado pelas mudanças nos procedimentos de pagamento, feito anteriormente para o Rio de Janeiro e agora para Lisboa, e anexou um documento assinado por Filippe de Barros Vasconcellos, em que este atestava não ter dívidas vencidas de Meirelles.

A polêmica em torno de Meirelles teve seqüência com a publicação no Conciliador de uma carta assinada pelo Inimigo da calúnia, que acusou Meirelles de iniciar uma campanha pelo jornal $^{96}$ contra os contratadores de carne verde que o venceram na disputa pelo abastecimento da cidade para o ano de 1823. Retomando o tema das dívidas de Meirelles para com a Junta da Fazenda, o autor informou sobre um requerimento lido na sessão das Cortes de nํ 387, em que Meirelles solicitou o parcelamento de suas dívidas, supostamente agravadas pela não renovação do contrato de abastecimento. Em resposta, o Investigador da mentira ${ }^{97}$ acusou o Inimigo da calúnia de ser financiado por Honório Teixeira e lembrou que o novo contratador, Francisco do Valle Porto, era presença constante nas "insidiosas, caluniosas e brejeiras representações impressas em Lisboa e assinadas pelos 48, 56 e 66 conspícuos desta cidade"98. A derrota de Meirelles e a vitória de um "abaixo-assinado"99 como contratante de carne verde evidenciam a complexidade das disputas que se travavam em torno da administração provincial, sempre pautadas pela obediência ao governo português.

\footnotetext{
${ }^{95}$ Conciliador, suplemento ao no $82,24 / 4 / 1822$, p. 6.

${ }^{96}$ Meirelles foi acusado de ser o mentor de uma carta assinada pelo sertanejo Raymundo José Nogueira, e publicada no Conciliador no 117, denunciando calotes aplicados pelos novos contratadores na compra de rebanhos, prática que inexistiria no período em que Meirelles foi o contratador.

${ }_{97}$ Conciliador, suplemento ao ํㅜㄴ 130, 9/10/1822, p. 3.

${ }^{98}$ Ibidem.

${ }^{99} \mathrm{Na}$ verdade, de três "abaixo-assinados". Valle Porto tinha como sócios no negócio de abastecimento de carne verde Honório José Teixeira e José Joaquim Vieira Belfort. Tal contrato vigorou entre 1823 e 1825. Argos da Lei, № 14, 22/2/1825, p. 1-2.
} 
Se a derrota nas eleições de fevereiro arrefeceu o ânimo dos opositores, a composição de uma Junta de Governo alterou, ao menos provisoriamente, o acesso à Tipografia Nacional do Maranhão, o que viabilizou, internamente, a publicização de alguns "papéis de oposição". Em março de 1822, era publicado o primeiro número da Folha Medicinal, pertencente ao abaixo-assinado Manoel Rodrigues de Oliveira, o mesmo que intentara, sem sucesso, a publicação da Gazeta da Verdade.

Mais que uma "concessão constitucional", a impressão do novo periódico parece expressar um momento de rearranjo político, marcado sobremaneira pela saída de Pinto da Fonseca da província, juntamente com o seu "Estado-Maior", primeiro momento de organização da política provincial a partir de seus quadros, cidadãos nascidos ou há muito radicados na província. O objetivo maior de Oliveira era recuperar a "História da regeneração política da província", principal tema de suas páginas ${ }^{100}$, intuito que atingia especialmente a figura e a administração de Fonseca e, em menor escala, aqueles que 0 apoiaram e permaneciam na província. Ainda assim, as páginas da Folha Medicinal revelam o clima de tensão da cidade e os bastidores da política praticada por intermédio de impressos e abaixo-assinados.

Quanto ao acesso a Tipografia, Oliveira narrou suas desventuras desde a propositura da Gazeta da Verdade, frustrada pela já salientada "sobrecarga de trabalho" alegada pela Tipografia. Em março, retomou, com sucesso, as negociações com o desembargador José Leandro da Silva Sousa, presidente da Junta Administrativa da Tipografia, e com Costa Soares, que além de redator do Conciliador, era diretor da Tipografia. Porém, em mais de uma edição, Oliveira sintetizou as dificuldades financeiras, técnicas e administrativas impostas pela direção da Tipografia: obrigatoriedade de pagamento semanal - o Conciliador pagava mensalmente, com desconto de 25\%; boicote dos compositores, que invertiam propositalmente os tipos, dando outro sentido às palavras; e exigências, que considerava descabidas, no que respeitava as assinaturas que deveriam acompanhar o conteúdo e os documentos a serem impressos pelo jornal. Em constante atrito com Costa Soares, quase foram as "vias de fato", razão pela qual foi proibido de entrar no prédio da Tipografia ${ }^{101}$.

100 Das 10 edições localizadas, as 9 primeiras dedicaram generosos espaços para a narrativa dos acontecimentos de abril de 1821, com ênfase nas artimanhas de Fonseca para permanecer no cargo e na repressão que comandara contra os opositores. A edição $\mathrm{n}^{\circ} 10$ foi toda dedicada às notícias que chegavam do Rio de Janeiro e de São Paulo, motivos de preocupação e repúdio por parte do redator, como se verá.

${ }_{101}$ Folha Medicinal, no 3, 25/3/1822, p. 23-24 e no 8, 29/4/1822, p. 64. 
Já os abaixo-assinados, que ainda repercutiam, foram objetos de outro desentendimento, desta feita, entre o redator e Antonio Meirelles. Andando pela Praia Grande, Oliveira teria sido abordado por Meirelles - posteriormente acompanhado pelo também comerciante José dos Santos Monteiro, inicialmente, de forma cordata, para parabenizá-lo pelo jornal, ironia que se tornou mais clara à medida que as brincadeiras ficaram mais ríspidas. A certa altura, veio à tona a questão dos abaixo-assinados, considerados "patifes", por Meirelles e Monteiro; como resposta, ouviram que muitos outros patifes existiam, mas não assinavam tais documentos. Por fim, Meirelles quis apertar a mão de Oliveira para lhe propor um duelo ${ }^{102}$, recusado pelo redator ${ }^{103}$.

Outro duelo, de formato mais recente, dava seus primeiros passos nos prelos da província. Depois de Oliveira, foi a vez de Manoel Zacheo "estrear" na Tipografia. De volta ao Maranhão após a saída de Fonseca, Zacheo publicou, em maio, dois folhetos atacando, respectivamente, os "déspotas do Rio de Janeiro" e a inoperância do frei Nazaré, então presidente da Junta ${ }^{104}$; em outubro, publicou Os últimos adeoses do Epaminondas Americano ao Despotismo ${ }^{105}$, referência ao despotismo de Pinto da Fonseca, que se despedira do Maranhão em fevereiro de 1822, e também ao que considerava como últimas manifestações de tais práticas na província, a serem definitivamente sepultadas com algumas medidas que sugeria e, com a aguardada finalização do trabalho das Cortes.

A trajetória de Zacheo como integrante da oposição provincial diverge um pouco da de outros publicistas e dos abaixo-assinados aqui apresentados. Derrotado em seu propósito de eleger uma Junta Provincial, em abril de 1821, enviou às Cortes, dois meses depois, o manifesto A Sua Majestade Nacional e Real em Cortes de Lisboa, o

\footnotetext{
102 Evidentemente, discussões ríspidas e lutas corporais também compuseram as disputas políticas suscitadas, desde abril de 1821, nas ruas, tropas, e em reuniões no teatro e praças públicas. Em outro exemplo recuperado pela Folha Medicinal, dois militares - Bernardo Pereira de Berredo e Joaquim Raimundo Marques - se atracaram no Largo do Carmo, no dia 8 de abril de 1821, logo após a celebração de uma missa. O motivo teria sido a melhor forma de governo a ser instaurada. Folha Medicinal, ํㅡ 5, 8/4/1822, p. 38-39. Lembro que, posteriormente, Berredo assinou o Protesto... e o Requerimento..., enquanto Marques foi promovido ao comando do Regimento de Milícias, segundo Mesquita, "por ser anticonstitucional". Mesquita (1821). Op. cit., p. 5.

${ }^{103}$ Folha Medicinal, no $4,1 / 4 / 1822$, p. 28.

104 Zacheo, Manoel Paixão dos Santos (1822c). Carta do Epaminondas Americano ao Ilmo e Exmo Sr. D. Romualdo de Souza Coelho. Bispo do Grão Pará e Deputado em Cortes Gerais. Maranhão: Imprensa Nacional, Biblioteca do Itamaraty e Zacheo, Manoel Paixão dos Santos (1822d). Manifesto do Epaminondas Americano sobre a suspensão dos padres Fr. Joaquim Jerônimo de Castro e Silveira e Fr. Ignácio Guilherme da Costa, do Convento de Nossa Senhora das Mercês, da cidade do Maranhão. Maranhão: Tipografia Nacional, Biblioteca do Itamaraty.

${ }^{105}$ Zacheo (1822b). Op. cit. O folheto era vendido na loja de Honório José Teixeira, provável espaço de movimentação política, o que incluía o recolhimento de assinaturas. Para o anúncio, ver Conciliador, no 148, 11/12/1822, p. 6.
} 
Epaminondas Americano sobre a Revolução do Maranhão e, à Câmara, um requerimento solicitando que Pinto da Fonseca jurasse solenemente as bases da Constituição ${ }^{106}$, razão para o ordenamento de sua prisão. Fugitivo desde então, provável razão para não assinar o Protesto... e o Requerimento..., imprimiu em Portugal quatro folhetos, encaminhados às Cortes e ao rei. Nesses escritos, para além de uma narrativa das perseguições sofridas, apresentação de provas de inocência e ataques aos responsáveis pelas fugas, prisões ou deportações, comuns à época, tais elementos coadjuvam uma questão maior: a síntese das expectativas geradas pelo constitucionalismo português, seguida de proposições que garantissem o exercício dos preceitos constitucionais.

Fundamentado nos pilares que, acreditava, deveriam sustentar a nova ordem, fundiu propostas objetivas e reformas mais estruturais. Defendeu a extinção do Tribunal da Relação do Maranhão, a substituição de Fonseca e a criação de mecanismos de regulamentação e garantia da liberdade de expressão, base de três projetos de lei que encaminhou às Cortes. Num dos trechos da proposição, pode-se ler:

A maledicência, ou murmuração de qualquer autoridade pública, civil ou militar, ou eclesiástica, feita no teatro, no púlpito, na igreja, na audiência, ou em papéis públicos, nunca será considerada delito público, ou objetos de ações populares, quando não for acompanhada de fatos, ou persuasões que se encaminhem evidentemente a ofender a Constituição da Monarquia, o sossego público, ou a Real Pessoa do Soberano, ou sua Augusta Família. Aquele que se acreditar injuriado, poderá intentar em juízo civilmente as ações, que lhe competirem, e o injuriante embargará com a verdade, ou publicidade do convicto suporto e será obrigado a prová-la, e neste caso relevada a pena se a maledicência for a respeito da vida, ou conduta pública do injuriado, ou mau desempenho de seus deveres, ou jurisdição, e não de sua pessoa, ou vida particular ${ }^{107}$.

Estabelecendo princípios que abrangiam todo o Império português, mas com os olhos fixados no Maranhão, o texto acima localizou os "espaços de murmúrios" e a ação dos "papéis públicos" no novo debate político, e reforçou o princípio do processo de formação de culpa, inclusive para os "crimes de opinião", com o intuito de diminuir a prática de ordens de prisão arbitrárias, como teria sido a dele.

Essas preocupações em torno das opiniões publicamente manifestadas expressam a importância das disputas em torno da legitimidade de tais ideias, novidade do tempo.

\footnotetext{
${ }^{106} \mathrm{O}$ requerimento é de 28 de junho de 1821. Fonseca o recusou sob a alegação de que aguardava ordens das Cortes, já que um prévio juramento fora realizado em abril de 1821. Como resposta, afirmou que não receberia ordens de gazetas, referência aos primeiros papéis que circularam na Europa contra a sua permanência no poder após o 6 de abril. As bases da Constituição portuguesa foram juradas no Maranhão em 19 de agosto de 1821. A ordem de prisão contra Zacheo foi expedida quatro dias depois.

${ }^{107}$ Zacheo (1822a). Op. cit., p. 5.
} 
Noutro folheto, Zacheo acusou as autoridades de "perfilhar a opinião pública", tornando-a sinônimo de suas vontades: "20 ou 30 cidadãos não podem formar opinião pública verdadeira, e destruir aqueles todos, muito mais se aqueles poucos forem apoiados por aquela justiça" "108. Já tratei aqui da "batalha dos números" e sua relação com a legitimidade das demandas sustentadas, apenas registro outra conexão, estabelecida pelo autor, entre "opinião pública verdadeira" e práticas constitucionais. Assim, as autoridades constituídas e seus agentes não poderiam formar uma "opinião pública verdadeira", porque foram forjadas no "despotismo": "Só pode ser Constitucional puro quem já o era no desejo, e não tinha empregos de Justiça, e fazenda no Brasip'109. Em tais debates sobre a "pureza" dos envolvidos, voltava à tona a recorrente questão do acesso aos melhores cargos e demais empregos públicos.

Não obstante os entraves atribuídos ao "despotismo" ainda vigente, o direito de "murmurar e escrever" foi exercido com o consentimento ou à revelia das autoridades. Mesmo o Conciliador, ao refutar correspondências, abaixo-assinados e folhetos, transcreveu seus conteúdos, permitindo a um maior número de cidadãos o acesso às ideias e interesses que se confrontavam. A disputa pela "opinião pública", conformada pelos autores a partir das premissas que os norteavam, sustenta a percepção de uma cidade agitada pelas "novidades da política", assertiva que não implica o reconhecimento de um "desejo de emancipação", consolidado pela "adesão" do Maranhão ao Império do Brasil, em julho de 1823.

\section{Fontes}

\subsection{Manuscritos}

\section{a) Arquivo Histórico Ultramarino - CD-ROM}

\section{Catálogo dos manuscritos avulsos relativos ao Maranhão existentes no Arquivo Histórico Ultramarino - Lisboa (1614-1833):}

Carta de Miguel Inácio dos Santos Freire e Bruce ao rei D. João VI, solicitando que a tropa do Maranhão seja constituída por amantes da Constituição. Considera aos antigos governadores do Maranhão déspotas e que a atuação de Bernardo da Silveira Pinto da Fonseca foi vingativa. Solicita ainda a substituição de todo o pessoal dos empregos

\footnotetext{
108 Zacheo, Manoel Paixão dos Santos (1822e). Discurso do arguelles da Província do Maranhão a S. Magestade Nacional e Real em Cortes Gerais sobre a opinião pública, liberdade civil e comércio de escravatura, Lisboa: Na impressão de João Nunes Esteves, BN, Seção de Obras Raras, p. 5.

${ }^{109}$ lbidem, p. 6-7.
} 
públicos do Maranhão (1821). São Luís do Maranhão, 9 de novembro de 1821. CU 009, cx. 167 , doc. 12.183 .

Representação dos moradores do Maranhão ao rei D. João VI, informando sobre o Estado do Maranhão e solicitando que o governador, o juiz de fora, entre muitos outros sejam substituídos (1821).

\section{b) Arquivo Nacional - RJ}

\section{Coleções/Fundos:}

\section{Fundo Desembargo do Paço}

Processo movido contra Miguel Ignácio dos Santos Freire e Bruce entre os anos de 1811 e 1813. Arquivo Nacional, caixa 161, pct. 1, doc. 2.

\section{c) Arquivo Nacional da Torre do Tombo - Lisboa}

Autos da devassa a que procedeu o governador do Maranhão por ordem do governador das armas daquela província, contra os perturbadores do sossego público na capital da mesma província, que se opuseram ao sistema constitucional. Ministério dos Negócios eclesiásticos e de justiça, maço 102, no 1.

\section{d) Biblioteca Nacional - RJ}

Acontecimentos do Maranhão (1810). Bernardo José da Gama. Visconde de Goiana. Seção de Manuscritos, 11, 3,12.

Coleção de Documentos Biográficos:

C 210,020 - Honório José Teixeira

C 383,14 - José Joaquim Vieira Belford

\section{e) Biblioteca Pública Benedito Leite - MA}

Sousa, José Leandro da Silva. Concessão de $25 \%$ de desconto para imprimir o Conciliador (23/12/1821). Seção de Manuscritos, 239 (245) M1 G2 E9.

\section{f) Instituto Histórico e Geográfico Brasileiro}

Exposição do Governador do Maranhão Bernardo da Silveira Pinto ao Congresso Português sobre o juramento à constituição que houver de fazer o mesmo Congresso, e estabelecimento do Governo Provisório (1821) 5 fls. São Luís, 30/4/1821. Lata 58, pasta 35.

Protesto de lealdade e reconhecimento do povo ao Rei. Abaixo-assinado dos cidadãos da província do Maranhão (1821). Coleção Instituto Histórico. Lata 400, pasta 10, doc. 2.

\subsection{Impressos}




\section{a) Folhetos}

Fonseca, Bernardo da Silveira Pinto da (s/d). Singela e verdadeira narração do começo, progresso e conclusão da Regeneração Política do Maranhão, no glorioso dia 6 de abril de 1821. Sem data e local de impressão. BN, Seção de Obras Raras, Coleção Benedito Ottoni.

Meirelles, Antonio José (1822). Manifesto do Commendador Antonio José Meirelles, da Cidade do Maranhão, desmentindo as monstruosas calúnias que o Bonifácio-mor, Honório José Teixeira, e seus sócios e assalariados levaram à presença do Soberano Congresso, em desabono da sua probidade e crédito mercantil. Lisboa: Typografia de M. P. de Lacerda, BNP.

Mesquita, José de Loureiro (1821). Manifesto de todos os acontecimentos e causa da Revolução da Província do Maranhão concluída em 6 de abril de 1821. Para servir de justificação aquelles que foram injustamente presos e perseguidos pelo despótico Governador daquela Província Bernardo da Silveira Pinto. Lisboa: Impressão de Alcobia. BN, Seção de Obras Raras.

Pizarro, Rodrigo Pinto (1832). Carta de um português emigrado acerca do ex-imperador do Brasil e do seu chamado manifesto. Lisboa (Paris, 20/2/1832). BN, Seção de Obras Raras.

Zacheo, Manoel Paixão dos Santos (1822a). Carta do arguelles da província do Maranhão ao IIImo. Exmo Sr. Fco Simões Margiochi. Deputado em Cortes. Lisboa: Na impressão de João Nunes Esteves. BN, Seção de Obras Raras.

(1822b). Os últimos adeoses do Epaminondas Americano ao despotismo.

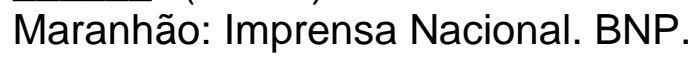

(1822c). Carta do Epaminondas Americano ao Ilmo e Exmo Sr. D. Romualdo de Souza Coelho. Bispo do Grão Pará e Deputado em Cortes Gerais. Maranhão: Imprensa Nacional, Biblioteca do Itamaraty.

(1822d). Manifesto do Epaminondas Americano sobre a suspensão dos padres Fr. Joaquim Jerônimo de Castro e Silveira e Fr. Ignácio Guilherme da Costa, do Convento de Nossa Senhora das Mercês, da cidade do Maranhão. Maranhão: Tipografia Nacional, Biblioteca do Itamaraty.

(1822e). Discurso do arguelles da Província do Maranhão a S. Magestade Nacional e Real em Cortes Gerais sobre a opinião pública, liberdade civil e comércio de escravatura. Lisboa: Na impressão de João Nunes Esteves, BN, Seção de Obras Raras.

\section{b) Jornais}

(O) Argos da Lei - MA (1825)

(O) Conciliador - MA (1821-1823)

(O) Correio Braziliense - Londres (1808-1823) 
Diário do Governo - RJ (1823-1824)

(A) Folha Medicinal do Maranhão - MA (1822)

\section{c) Ofícios, bandos, proclamações e outros documentos públicos}

Sentenças proferidas em primeira instância, no juízo ordinário da Villa d'Alcântara, Comarca da Cidade de S. Luiz do Maranhão, e em sua confirmação, em segunda, na Relação da mesma Cidade a favor de José da Silva Maya d'Azevedo, e outros RR. Impressas a requerimento de Manoel Francisco Ramos, Commerciante da dita Capitania (1816). Lisboa: Officina de J. F. Monteiro de Campos.

\section{Referências Bibliográficas}

Costa, Yuri e Galves, Marcelo Cheche (2011). O Epaminondas Americano: trajetórias de um advogado português na Província do Maranhão, São Luís: Café e Lápis, Editora UEMA.

Galves, Marcelo Cheche (2010). "Ao público sincero e imparcial": Imprensa e Independência do Maranhão (1821-1826). Tese (Doutorado em História) - Programa de Pós-Graduação em História Social, Universidade Federal Fluminense, Niterói.

Lago, Antonio Bernardino Pereira do (2001). Estatística histórico-geográfica da Província do Maranhão, 2 ed. São Paulo: Siciliano.

Machado, André Roberto de Arruda (2006). A quebra da mola real das sociedades. A crise política do Antigo Regime Português na província do Grão-Pará (1821-1825). Tese (Doutorado em História) - Programa de Pós-Graduação em História Social, Universidade de São Paulo, São Paulo.

Marques, César Augusto (2008). Dicionário histórico-geográfico da província do Maranhão, 3 ed. São Luís: Edições AML (Notas e apuração textual de Jomar Moraes).

Moreira, Carlos Eduardo de Araújo (et al.) (2006). Cidades negras: africanos, crioulos e espaços urbanos no Brasil escravista do século XIX, São Paulo: Alameda.

Paixão e Dores, frei Manuel Moreira da (1972). Diário da armada da independência, 2 ed. Brasília: MEC / Instituto Nacional do Livro.

Souza, lara Lis Franco Schiavinatto Carvalho (1999). Pátria coroada: o Brasil como corpo político autônomo (1780-1831), São Paulo: UNESP.

Vieira da Silva, Luís Antonio (1972) História da independência da província do Maranhão (1822-1828), 2 ed. Rio de Janeiro: Companhia Editora Americana.(Coleção São Luís, v. $4)$.

Recebido para publicação em novembro de 2011.

Aprovado para publicação em dezembro de 2011. 